\title{
Management of Chronic Congestive Heart Failure Caused by Myxomatous Mitral Valve Disease in Dogs: A Narrative Review from 1970 to 2020
}

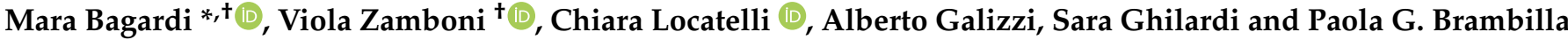 \\ Department of Veterinary Medicine, University of Milan, Via dell'Università n. 6, 26900 Lodi, Italy; \\ viola.zamboni@studenti.unimi.it (V.Z.); chiara.locatelli@unimi.it (C.L.); alberto.galizzi@unimi.it (A.G.); \\ sara.ghilardi@unimi.it (S.G.); paola.brambilla@unimi.it (P.G.B.) \\ * Correspondence: mara.bagardi@unimi.it; Tel.: +39-025-033-4054 \\ † These authors contributed equally to this work.
}

check for updates

Citation: Bagardi, M.; Zamboni, V.; Locatelli, C.; Galizzi, A.; Ghilardi, S.; Brambilla, P.G. Management of Chronic Congestive Heart Failure Caused by Myxomatous Mitral Valve Disease in Dogs: A Narrative Review from 1970 to 2020. Animals 2022, 12, 209. https://doi.org/10.3390/ ani12020209

Academic Editor: Cinzia Benazzi

Received: 22 December 2021

Accepted: 13 January 2022

Published: 16 January 2022

Publisher's Note: MDPI stays neutral with regard to jurisdictional claims in published maps and institutional affiliations.

Copyright: (C) 2022 by the authors. Licensee MDPI, Basel, Switzerland. This article is an open access article distributed under the terms and conditions of the Creative Commons Attribution (CC BY) license (https:// creativecommons.org/licenses/by/ $4.0 /)$.
Simple Summary: Myxomatous mitral valve disease (MMVD) is the most common acquired cardiovascular disease in dogs. The progression of the disease and the increasing severity of valvular regurgitation cause a volume overload of the left heart, leading to left atrial and ventricular remodeling and congestive heart failure (CHF). The treatment of chronic CHF secondary to MMVD in dogs has not always been the same over time. In the last fifty years, the drugs utilized have considerably changed, as well as the therapeutic protocols. Some drugs have also changed their intended use. An analysis of the literature concerning the therapy of chronic heart failure in dogs affected by this widespread degenerative disease is not available; a synthesis of the published literature on this topic and a description of its current state of art are needed. To the authors' knowledge, a review of this topic has never been published in veterinary medicine; therefore, the aim of this study is to overview the treatments of chronic CHF secondary to MMVD in dogs from 1970 to 2020 using the general framework of narrative reviews.

Abstract: The treatment of chronic congestive heart failure (CHF), secondary to myxomatous mitral valve disease (MMVD) in dogs, has considerably changed in the last fifty years. An analysis of the literature concerning the therapy of chronic CHF in dogs affected by MMVD is not available, and it is needed. Narrative reviews (NRs) are aimed at identifying and summarizing what has been previously published, avoiding duplications, and seeking new study areas that have not yet been addressed. The most accessible open-access databases, PubMed, Embase, and Google Scholar, were chosen, and the searching time frame was set in five decades, from 1970 to 2020. The 384 selected studies were classified into categories depending on the aim of the study, the population target, the pathogenesis of MMVD (natural/induced), and the resulting CHF. Over the years, the types of studies have increased considerably in veterinary medicine. In particular, there have been $43(24.29 \%)$ clinical trials, $41(23.16 \%)$ randomized controlled trials, 10 (5.65\%) cross-over trials, $40(22.60 \%)$ reviews, $5(2.82 \%)$ comparative studies, $17(9.60 \%)$ case-control studies, 2 (1.13\%) cohort studies, $2(1.13 \%)$ experimental studies, $2(1.13 \%)$ questionnaires, 6 (3.40\%) case-reports, 7 (3.95\%) retrospective studies, and $2(1.13 \%)$ guidelines. The experimental studies on dogs with an induced form of the disease were less numerous (49-27.68\%) than the studies on dogs affected by spontaneous MMVD (128-72.32\%). The therapy of chronic CHF in dogs has considerably changed in the last fifty years: in the last century, some of the currently prescribed drugs did not exist yet, while others had different indications.

Keywords: chronic congestive heart failure; therapy; dogs; myxomatous mitral valve disease; narrative review 


\section{Introduction}

Myxomatous mitral valve disease (MMVD) is the most common acquired cardiovascular disease in dogs [1]. It is estimated that approximately $10 \%$ of dogs presented to primary care veterinary practices have heart disease and that MMVD is the most common among them $(75 \%$ of canine cases of heart disease) [2,3]. Mitral regurgitation (MR) is the earliest hemodynamic event. The progression of the disease and the increasing severity of valvular regurgitation generate a volume overload of the left heart, leading to left atrial and ventricular remodeling and congestive heart failure (CHF) [1,4]. Particularly, remodeling secondary to MMVD is associated with characteristic histopathologic features, such as the expansion of the extracellular matrix with glycosaminoglycans and proteoglycans, the alteration of the valvular interstitial cell, and the attenuation or loss of the collagen-laden fibrosa layer. These lead to malformation of the mitral apparatus, biomechanical dysfunction, and mitral incompetence. Mitral regurgitation is the most common manifestation of MMVD and, in advanced stages, associated volume overload promotes progressive valvular regurgitation, left atrial and left ventricular remodeling, atrial tears, chordal rupture, and CHF, as stated before [5]. Dogs with MMVD present left-sided CHF clinical signs and a history of tachypnea, restlessness, respiratory distress, or cough [3]. Dogs with acute CHF need hospitalization, while patients with chronic CHF can be managed at home. The treatment of chronic CHF secondary to MMVD in dogs has not always been the same. In the last fifty years, the drugs utilized have considerably changed, and some have changed their intended use. The therapeutic protocols have also substantially changed over time. In 1970, the research and the literature were human medicine oriented, CHF in dogs was usually experimentally induced, and dogs were considered experimental animals. Later, the health and wellness of dogs have become primary endpoints; therefore, the research has been carried out on dogs as patients, and the therapy of CHF secondary to MMVD has been studied mainly on the spontaneous disease.

An analysis of the literature concerning the therapy of CHF in dogs affected by MMVD from 1970 to 2020 is not available, and a synthesis of the published literature on this topic, as well as a description of its current state of art, are needed.

The review on a specific subject can be systematic (SR) or non-systematic (narrative review-NR) and may include studies with different levels of evidence, different objectives, methods, and application areas [5]. Generally, an NR describes and appraises published articles that may be organized in chronological order, and the general framework includes different sections: introduction, literature search, central body/discussion, conclusion, and abstract.

To the authors' knowledge, an NR on the therapeutic management of CHF secondary to MMVD in dogs has not yet been published in veterinary medicine, and the aim of this study is to overview the treatments of this disease in dogs from 1970 to 2020 using the general framework of narrative reviews.

\section{Materials and Methods}

\subsection{Search Strategy}

The identification of the research engines was the first step of the literature selection process [5]. The most accessible open-access databases, PubMed, Embase, and Google Scholar, were chosen, and the searching time frame was set in five decades, from 1970 to 2020. Then the key concept "therapy of chronic congestive heart failure caused by mitral valve disease in dogs" was transformed into keywords through the thesaurus system used to index articles for PubMed (Medical Subject Heading-MSH). The most distinctive terms were "therapy", "chronic congestive heart failure", "dogs", and "mitral valve disease", and they were entered into the search bar [5]. Then the categories of the most used cardioactive drugs (i.e., diuretics, ACE-inhibitors, inodilator, inotropes) were also included in the searching string. 
The three basic Boolean operators, AND, OR, and NOT, were employed to focus the search. Since our topic contains multiple search terms, the operators were essential to connect various pieces of information to find exactly what we were looking for.

In accordance with the study design proposed by Ranganathan [6] and Röhrig, [7] the publications were classified as descriptive (case reports, case series, cross-sectional studies) or analytical, such as observational (cross-sectional studies, case-control studies, cohort studies) and experimental studies (clinical trials, randomized controlled trials, comparative studies, retrospective studies), or as questionnaires, reviews, and guidelines.

\subsection{Inclusion/Exclusion Criteria}

Inclusion criteria were full text and/or abstract available in the English language, better both, or at least the abstract, and studies focusing on the treatment of CHF secondary to MMVD in dogs published from 1970 to 2020. Furthermore, the selection also considered the origin of the CHF secondary to spontaneous or experimental-induced MMVD (MMVD ${ }^{\mathrm{EI}}$ ).

Studies concerning the therapy of acute CHF, right CHF, Bernheim Syndrome and ventricular interdependence, chronic $\mathrm{CHF}$ secondary to heart diseases different from MMVD, research on animals different from the dog, and studies dealing with surgical therapy of MMVD were excluded from this study.

The inclusion and exclusion criteria were applied, and the resulting flowchart is reported in Figure 1.

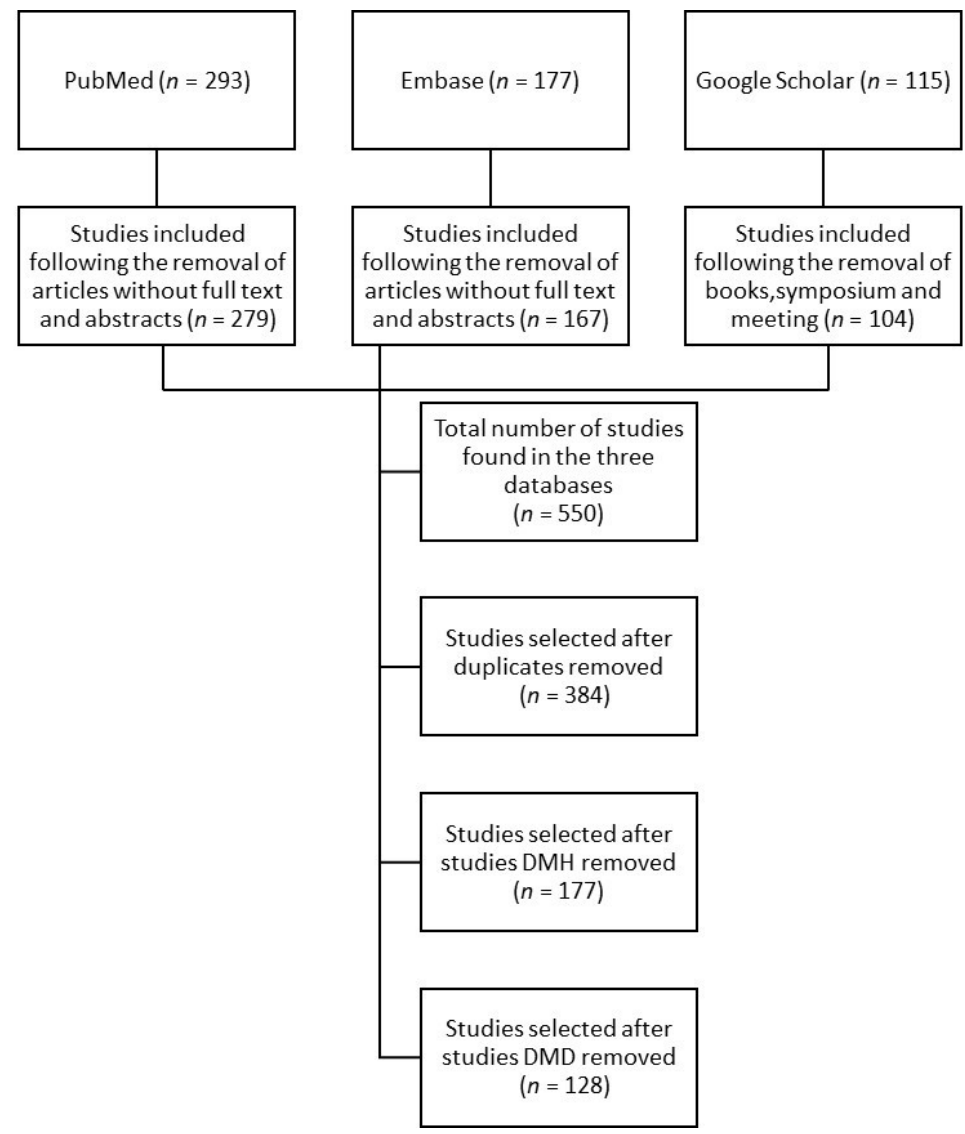

Figure 1. Flow chart of the literature selection process for the present article.

The selected studies were subsequently classified into categories depending on the aim of the study, the population target, the pathogenesis of MMVD (natural occurring or induced), and the resulting CHF. Three sets of studies were obtained: dogs as a model for humans $(\mathrm{DMH})$, dogs as a model for dogs $\left(\mathrm{MMVD}^{\mathrm{EI}}\right)(\mathrm{DMD})$, and dogs affected by naturally acquired MMVD as a model for diseased dogs (DNAD) (Table 1). 
The studies were also distinguished depending on the target of the journal (human medicine and veterinary medicine) (Table 1) [8].

Table 1. Subclassification of the studies into three categories.

\begin{tabular}{cccc}
\hline & DMH & DMD & DNAD \\
\hline Journal & Human medicine journal & Veterinary medicine journal & Veterinary medicine journal \\
Aim of the study & To test efficacy of medication of & To test efficacy of medication of & To test the therapy of CHF in dogs \\
Population & CHF in humans & CHF in dogs & Affected dogs \\
MMVD & Healthy dogs & Affected or healthy dogs & Natural \\
\hline
\end{tabular}

\section{Results}

\subsection{General Considerations}

The research engines provided 384 studies concerning the therapy of chronic CHF in dogs. PubMed proved to be more useful than Embase and Google Scholar for the search of older studies because it included more studies that better fitted our inclusion criteria (full text and/or abstract in English) (Figures 2 and 3).

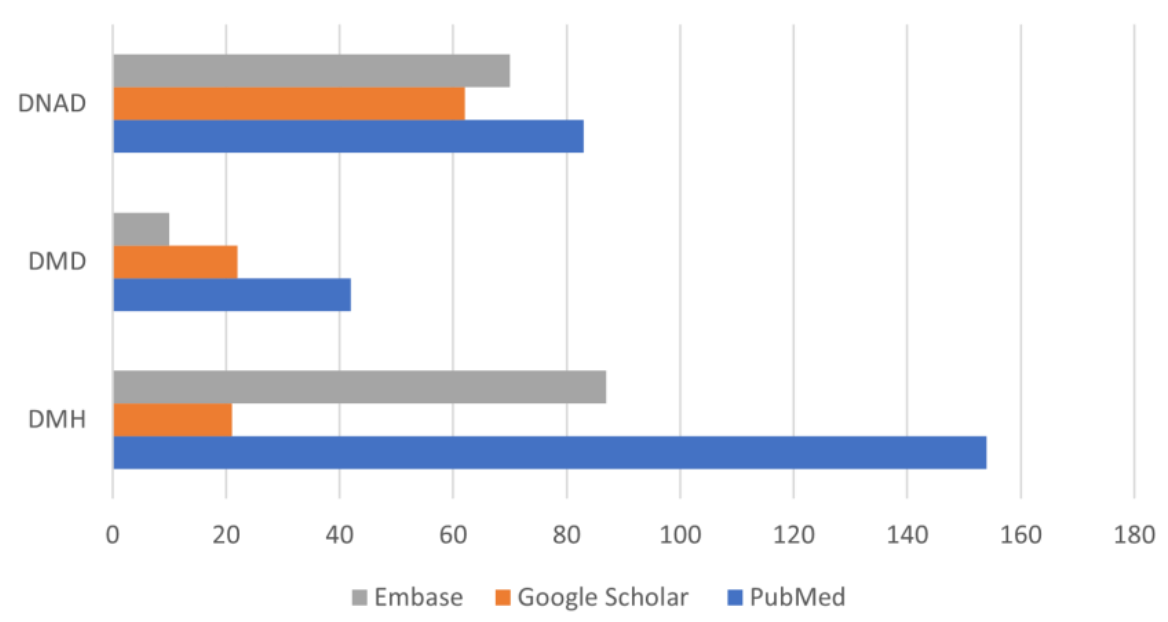

Figure 2. Number of studies identified in the three databases and allocated into three categories.

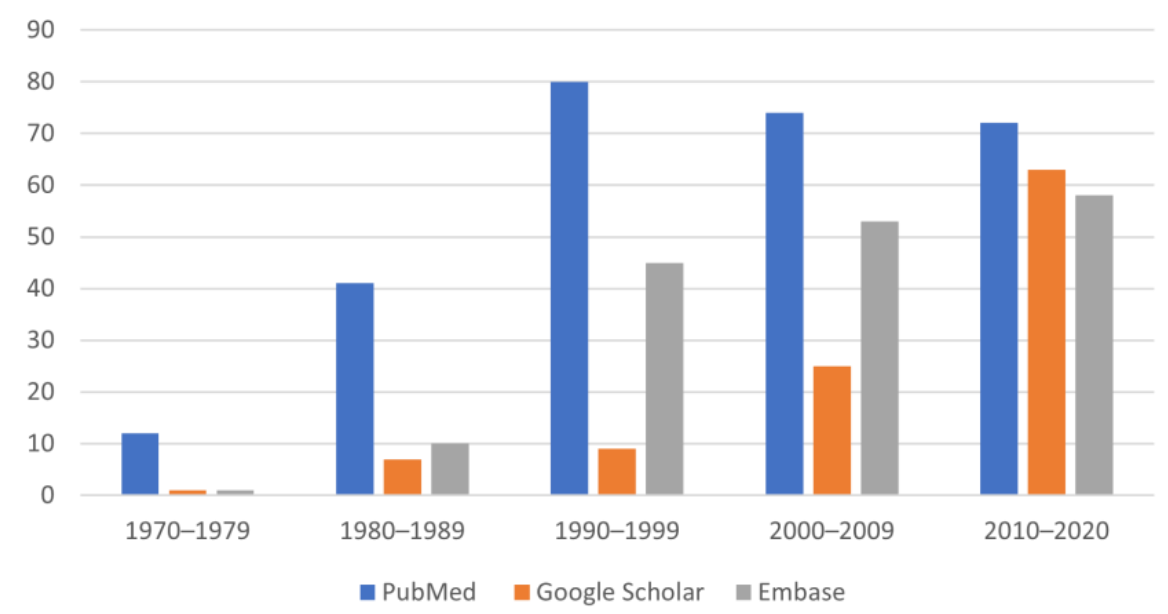

Figure 3. Numerousness of studies on CHF in dogs found in each database and in all decades.

The studies published in veterinary medicine journals resulted in $43(24.29 \%)$ clinical trials, $41(23.16 \%)$ randomized controlled trials, $10(5.65 \%)$ cross-over trials, $40(22.60 \%)$ 
reviews, $5(2.82 \%)$ comparative studies, 17 (9.60\%) case-control studies, $2(1.13 \%)$ cohort studies, 2 (1.13\%) experimental studies, 2 (1.13\%) questionnaires, $6(3.40 \%)$ case-reports, $7(3.95 \%)$ retrospective studies, and $2(1.13 \%)$ guidelines (Figure 4$)$.

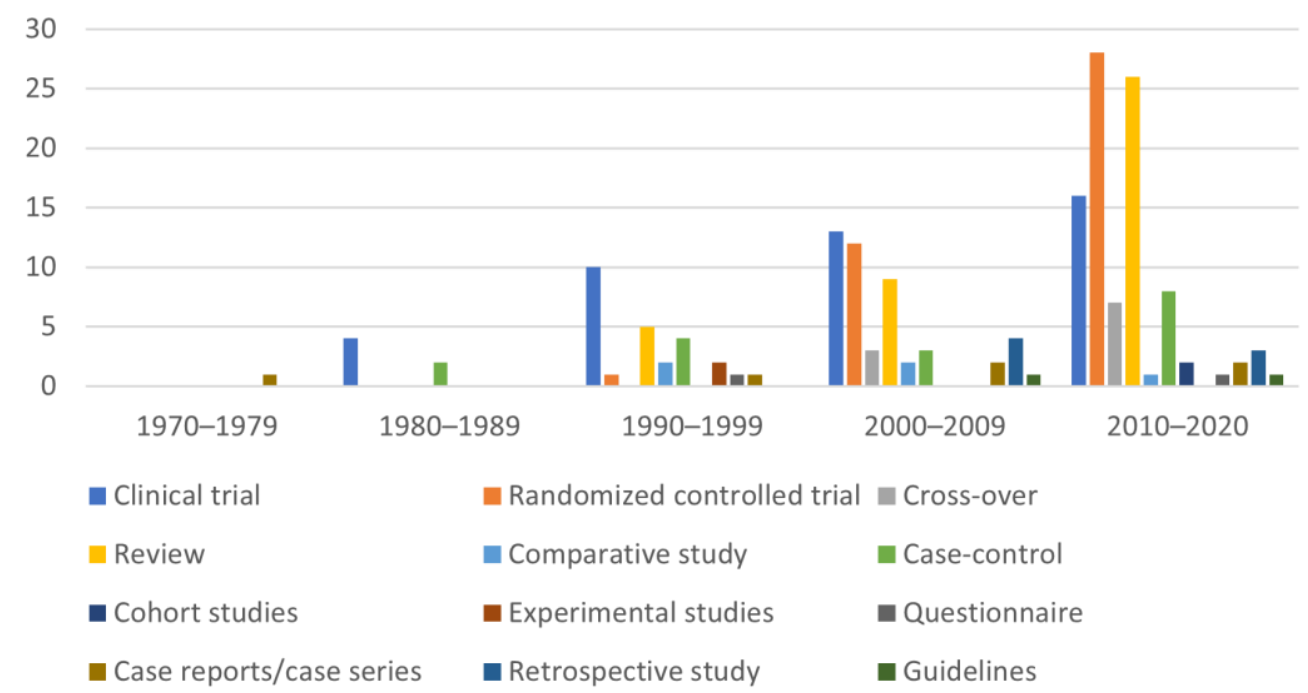

Figure 4. Subdivision of the studies published in veterinary medicine journals (DMD and DNAD) according to the type of study in the five decades taken into consideration. It is interesting to note that in the last decades the typologies of veterinary medicine studies were more diversified than in the last century.

In the fifty years considered, however, the experimental studies published in veterinary medicine journals (DMD) were less numerous (49-27.68\%) than the studies on dogs affected by spontaneous MMVD (128-72.32\%) (Figure 5).

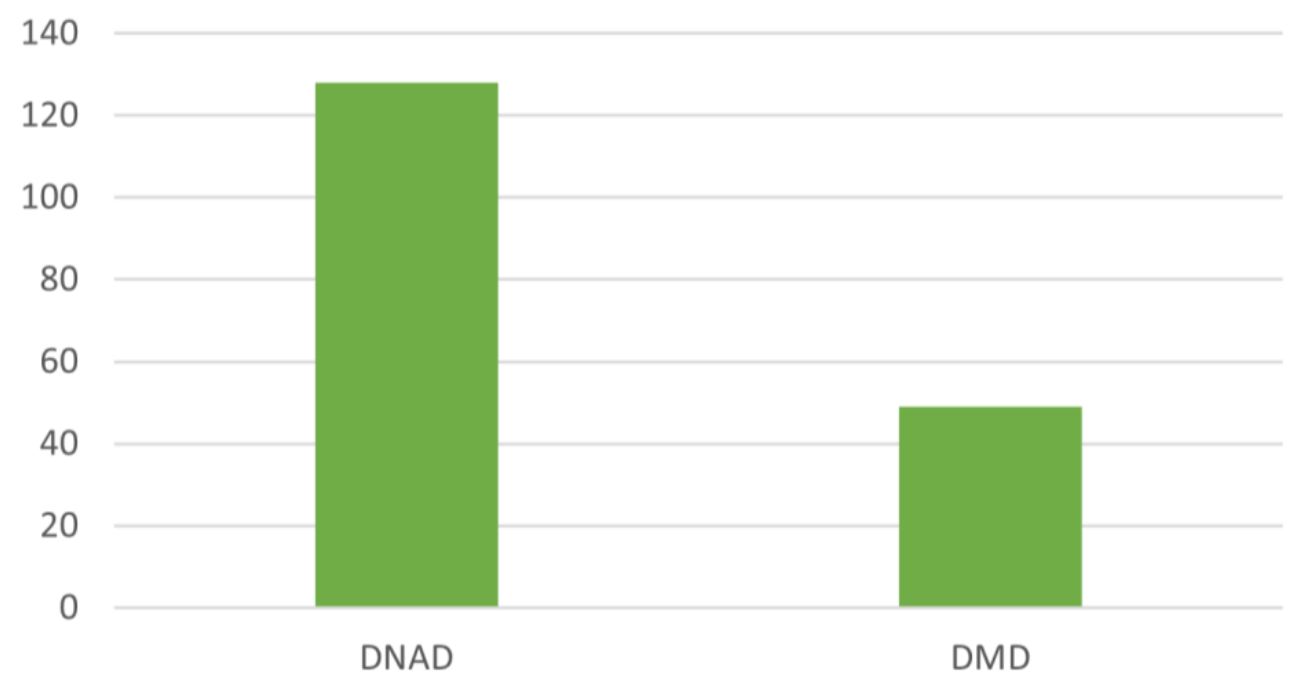

Figure 5. Comparison of numerous studies published in veterinary medicine journals.

Experimental studies in which the CHF was induced in healthy dogs to test the therapeutic efficacy (human or canine) show the highest timeframe variability in the distribution (Figure 6). 


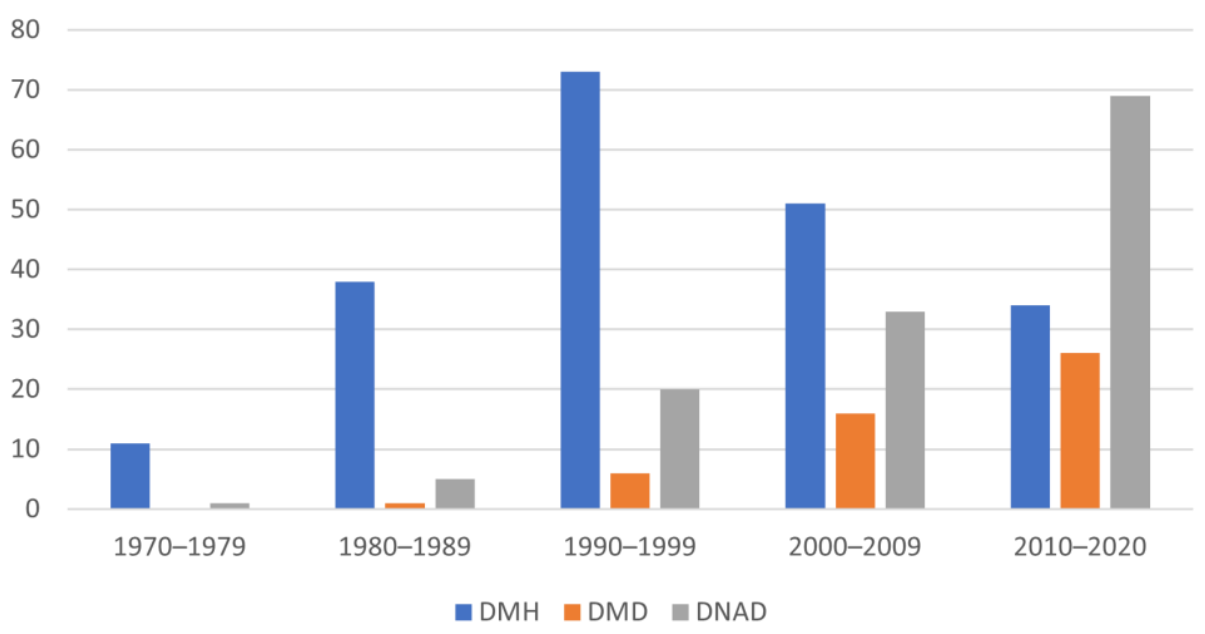

Figure 6. Studies found in each database, allocated into three categories, and distributed in the considered decades. It is interesting to note the increased number of studies carried out on dogs with a spontaneous disease in the last decades compared to studies in which the dog was a model for testing drugs potentially useful for the treatment of human CHF.

\section{2. $1970-1979$}

In the 1970s, the literature search performed on the 3 research engines resulted in 11 studies, all of them published in human medicine journals [9-19]. The mitral valve incompetence was always experimentally induced in dogs, surgically and/or pharmacologically, to obtain a low cardiac output. The goal of these studies was to test drugs for the treatment of CHF in humans. The database that proved most useful for finding the oldest studies was PubMed (Figure 3).

In this decade, only one case report describing spontaneous CHF in dogs was published [20]. Thus, it can be inferred that pharmacologic management of canine CHF secondary to MMVD was not yet thoroughly investigated in this decade.

Furthermore, the milestone of therapy of the canine spontaneous chronic $\mathrm{CHF}$ due to MMVD was reported in a book [21]; therefore, it was not accessible to most of the researchers [18]. The therapeutic protocol included the same drugs used today but with very different intents, as reported in Figure 7 [21].

1970

- Digoxin, diuretics, antiarrhythmics

\section{$\underline{2000}$}

- ACE inhibitors, diuretics, pimobendan, spironolactone

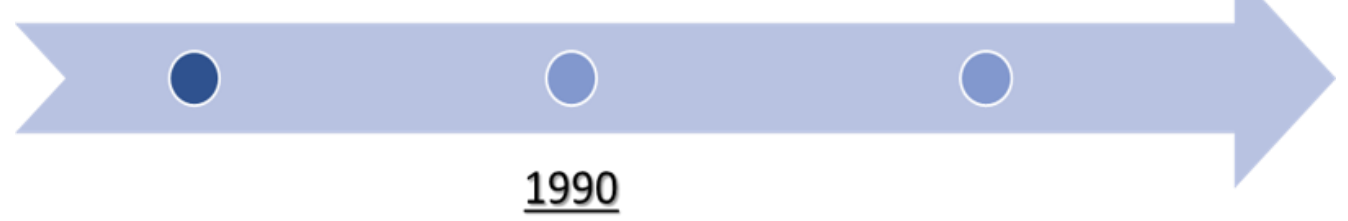

- ACE inhibitors, diuretics

Figure 7. Timeline representing the main categories of drugs used for canine CHF therapy over the past fifty years.

\section{3. $1980-1989$}

During the 1980s, canine experimental studies increased compared to the 1970s [22-59], and they were mostly published in human medicine journals (DMH); in this decade, this type of study was still the most common (Figure 3). However, an experimental study 
carried out on dogs, that was then published in a veterinary medicine journal (DMD), was identified [60].

In addition to the above-mentioned experimental studies, five others were published on CHF management in dogs affected by spontaneous MMVD. Two studies tested the use of hydralazine [61,62], one tested milrinone [63] and the two others tested digitalis glycosides [64,65]. In the 1970s and 1980s, the digitalis glycosides were considered the standard therapy of the canine CHF, and the studies were mostly focused on finding the appropriate and individual therapeutic dosage; in fact, in some cases, the same dosage provided different results. For example, in one of the two publications, the digoxin dosage administered in 10 patients was $0.01 \mathrm{mg} / \mathrm{kg}$ lean body mass twice daily; however, serum digoxin concentrations in patients differed.

\subsection{0-1999}

The 1990s registered the highest number of experimental studies published in human medicine journals [66-138]. This highlights that the research concerning the therapy of human CHF was a key point along this period and that the dog was considered one of the most common and useful experimental animals. Furthermore, the number of experimental studies published in veterinary medicine journals also increased compared to the previous decade [139-144]. The efficacy of the therapy of CHF in dogs affected by spontaneous MMVD was evaluated, and the published studies were more numerous than in the previous twenty years. Many of the studies tested the effect and the efficacy of ACE inhibitors (captopril, enalapril, quinapril, ramipril, and benazepril), and over these ten years, they were introduced in the standard therapy of chronic CHF in dogs affected by MMVD [145-156]. In particular, it is important to mention the COVE study [147], the IMPROVE study [148], the BENCH study [156], and the LIVE study [155], which significantly contributed to the evaluation of the efficacy and effect of enalapril and benazepril. The ACE inhibitors were administered at different dosages: benazepril from a minimum of $0.25 \mathrm{mg} / \mathrm{kg}$ once daily, captopril $0.5 \mathrm{mg} / \mathrm{kg}$ three times daily, quinapril $0.5 \mathrm{mg} / \mathrm{kg}$ once daily, enalapril from $0.38 \mathrm{mg} / \mathrm{kg}$ twice daily to $0.5 \mathrm{mg} / \mathrm{kg}$ once or twice daily, and ramipril $0.125 \mathrm{mg} / \mathrm{kg}$ once or twice daily. Moreover, two studies have been published on milrinone [157,158] (which was administered at a dosage of 0.5 to $1 \mathrm{mg} / \mathrm{kg}$ twice daily), two on propentophylline $[159,160]$, and one on the effect of fish oil when added to the diet of dogs with CHF [161]. These studies were isolated, and the research on these molecules has not been followed up in veterinary medicine. In 1991 and 1998, the first two systematic reviews, one on the management of chronic CHF in dogs [162] and one on afterload reducing agents [163], were published.

In 1995, the results of the first documented experience of a cardiological survey in veterinary medicine were published [164]. The questionnaire was submitted to veterinarians, and the aim was to analyze the preferences on the medications prescribed to treat heart diseases in dogs [164]. Interestingly, diuretics appeared to be the most common category $(74 \%)$, while positive inotropic agents (digitalis glycoside), which were the milestone of the therapy of CHF in dogs up to the 1980s, were the least used drugs (20\%). Thus, from this decade on, the use of digitalis glycoside as the main therapeutic agent started decreasing [164].

\subsection{0-2009}

During the 2000s, the experimental studies that tested in dogs the efficacy of drugs used for CHF in humans (DMH) were fewer than in the previous decades [165-215]. In contrast, there was an increase in studies published in veterinary medicine journals that evaluated the treatment of CHF in dogs, both experimental [216-231] and carried out in patients with spontaneous MMVD. The scientific publications on drugs tested in dogs with CHF secondary to MMVD (DNAD) were more numerous than in previous years, and many studies were performed on ACE inhibitors [232-235], $\beta$-blockers [236-238], sildenafil [239,240], amiodarone [241], diuretics [242], isosorbide 5-mononitrate [243], and 
amlodipine [244]. In particular, the different ACE inhibitors were administered at different dosages: quinapril and enalapril at $0.5 \mathrm{mg} / \mathrm{kg}$ once daily, ramipril at $0.125 \mathrm{mg} / \mathrm{kg}$ once daily, perindopril at $0.2 \mathrm{mg} / \mathrm{kg}$ once daily, benazepril from 0.25 to $1 \mathrm{mg} / \mathrm{kg} /$ day. Pimobendan was also introduced in the standard therapeutic protocol of CHF secondary to MMVD [245-249]. Some studies compared pimobendan and ACE inhibitors, such as the QUEST study [250], and the results showed that pimobendan, in combination with the standard therapy (diuretics and digoxin), administered at a dosage of $0.4-0.6 \mathrm{mg} / \mathrm{kg} /$ day prolonged the expectancy and quality of life in patients affected by CHF secondary to MMVD [251]. Digitalis glycosides definitively changed their intended use, and, differently from their previous indication, they were administered to decrease the excitability of the atrioventricular node and the ventricular rate in presence of atrial fibrillation (AF) [252]. At the end of this decade, guidelines for the diagnosis and treatment of canine chronic valvular heart disease were published for the first time [2]; the recommended drugs were furosemide, ACE-I, and pimobendan. The majority of the panelists recommended the administration of $\beta$-blockers, digoxin, or diltiazem as antiarrhythmics, and cough suppressants and bronchodilators in the presence of cough. In this decade, the attention to dogs' diets increased, with particular interest for sodium restriction [253-257]. The reviews published in these ten years are much more numerous than in previous years because more studies were carried out to evaluate the therapy of CHF secondary to MMVD in dogs $[237,247,258-264]$; these data are important because the reviews identify, evaluate, and summarize the outcomes of the studies carried out in a specific period.

\section{6. $2010-2020$}

From 2010 to 2020, as well as in the early 2000s, there was a decrease in experimental studies carried out on dogs published in human medicine journals and an increase in studies published in veterinary medicine journals. DMH studies were 34 [265-298], the DMD studies were 25 [299-324], and 69 studies concerning the therapy of CHF secondary to spontaneous MMVD have been found in the literature. The research was profuse, and the drugs tested were numerous; in fact, the reviews published in these ten years regarding the therapy of CHF secondary to MMVD in dogs are 25 [325-349]. As in the previous decade, many studies have been published and many drugs have been tested on dogs with spontaneous disease, such as sildenafil [350-353], imatinib [354], atorvastatin [355,356], coenzyme q10 [357,358], amlodipine [359], BNP1-32 [360], and angiotensin receptor antagonists [361]. In this decade, several studies have been published on diuretics, with particular regard to torasemide (such as the TEST study [362] and the CARPODIEM study [363]). In these papers, the diuretic has been administered over a dose range of $0.13 \mathrm{mg} / \mathrm{kg} /$ day to $0.5 \mathrm{mg} / \mathrm{kg} /$ day, and spironolactone (an aldosterone receptor antagonist) has been administered at dosages from $0.49 \mathrm{mg} / \mathrm{kg}$ once daily to $2 \mathrm{mg} / \mathrm{kg}$ once daily. These drugs are very useful in the therapy of CHF secondary to MMVD in dogs [362-369].

Studies focused on other standard therapy drugs (pimobendan or ACE inhibitors, such as the QUEST and the EPIC studies [370,371], respectively, which focused on symptomatic and asymptomatic dogs with cardiac remodeling) or drugs used in case of complications related to this syndrome (such as $\beta$-blockers, amlodipine, and digoxin) [372-384] have also been published. In the QUEST and EPIC studies, pimobendan was administered over a dose range of 0.4 to $0.6 \mathrm{mg} / \mathrm{kg} /$ daily and benazepril over a dose range of 0.25 to $1 \mathrm{mg} / \mathrm{kg} /$ daily. The addition of the ACE inhibitor ramipril to pimobendan and furosemide has been demonstrated not to have any beneficial effect on survival time in dogs with CHF secondary to MMVD [384].

In 2019, the newly updated guidelines were published according to the most recent results [3]. The recommended diuretic was not only furosemide but also torasemide. Moreover, spironolactone was recommended in addition to the classic triple therapy for its aldosterone-antagonist effect [3].

Other studies evaluated the clinical findings and the survival time following the administration of the drugs [385], X-ray and ultrasound images after the treatment [386], and 
the "aldosterone breakthrough" following the administration of ACE inhibitors [387]. Furthermore, a study on a myostatin antagonist used to counteract cardiac cachexia secondary to CHF has also been published [388]. In recent years, the evaluation of NT-pro BNP levels following the cardiological treatment has gained a lot of interest; in fact, low levels of this molecule indicate a better prognosis $[389,390]$. Cohort studies in veterinary medicine are rarely carried out because of high costs and long-time needing; in the period considered for this narrative review, only two have been found in the literature [391,392]. A questionnaire published in 2015 was also very interesting since it is useful to compare how dogs' CHF therapy has changed from that which was used twenty years earlier [393].

\subsection{1-Last Minute Update}

The never-ending story of the medical strategies for the treatment of MMVD in dogs is far from the conclusion.

In 2021, the last clinical trial, named the BESST study, has been published after the conclusion of this narrative review [394]. The BESST is a multicentric double-blind study that compared the combination of benazepril and spironolactone in the management of CHF in dogs affected by MMVD [394]. Particularly, the results of this study show that the combination of spironolactone and benazepril is effective, safe, and superior to benazepril alone when used with furosemide for the management of mild, moderate, or severe CHF caused by MMVD in dogs.

\section{Discussion}

The therapy of chronic CHF in dogs has considerably changed in the last fifty years. In the last century, some of the currently prescribed drugs did not exist yet, while others had different indications [21]. Digitalis glycosides are the oldest medication used for the treatment of chronic CHF in dogs, and despite the risks of intoxication or death secondary to their overdose, the drug is still used. For a very long time, digitalis glycosides have been administrated because of their positive inotropic and negative chronotropic effect, and their dromotropic action. Furthermore, they were used to relieve clinical signs as cough, dyspnea (secondary to pulmonary edema), and ascites, frequently found in severe CHF. Currently, their clinical use has changed: the presence of $\mathrm{AF}$, quite a common complication of MMVD, especially in medium- and large-breed dogs, is the first indication of adding the digitalis glycosides to the therapeutic protocol. Nevertheless, digoxin is the most common drug used to ensure adequate control of the ventricular rate in patients with $\mathrm{AF}$, alone or associated with diltiazem, as reported by the literature [252,377].

Diuretics are another pivotal category of drugs that makes the history of the cardioactive protocols. In 1970, diuretics were administered only if therapy with glycosides alone failed. Nowadays, they are one of the most useful drugs used for the treatment of chronic $\mathrm{CHF}$ in dogs. The oldest diuretics were mercurials, thiazides, furosemide, spironolactone, and ethacrynic acid. Furosemide was administered in case of the development of resistance to thiazides, so it was not the first diuretic of choice [348]. To the present day, the therapeutic protocol of chronic CHF in dogs includes furosemide, the most widely used diuretic.

Interestingly, the role of spironolactone in cardiac protocols changed its use: in the last century, it was administered in association with thiazides to avoid hypokalemia, while it is now one of the main drugs for the treatment of chronic CHF because of its antagonist activity to mineralocorticoid receptors. Spironolactone, added to the therapy with pimobendan, diuretic, and an ACE inhibitor, has been shown to increase survival time in dogs with chronic CHF secondary to MMVD [362]. The main antiarrhythmics drugs used in the 1970s were quinidine sulphate, procainamide, and lidocaine. Currently, as previously mentioned, the digoxin-diltiazem protocol is well tolerated, and $\beta$-blocker antiarrhythmics can be used $[215,219]$. ACE inhibitors were introduced into dogs' treatment protocol in the early 1990s, while pimobendan was introduced in the 2000s.

The renin-angiotensin-aldosterone system (RAAS) activation can be compensatory in the early stages of cardiovascular and renal diseases, but its long-term activation is 
maladaptive [345]. In patients with heart failure, relative increases in plasma renin activity and the blood aldosterone concentration are considered markers of, and contributors to, the hemodynamic and anatomic derangements of this syndrome [345]. However, the literature shows that the more we learn about this system, the broader and more complex it becomes. Continuous research into this complex system is necessary to improve medical therapies for cardiovascular and renal diseases, allowing us to modulate this system and improve clinical outcomes more adeptly [345].

Following this research, other considerations emerge: fifty years ago, the research was mainly focused on the therapy of human CHF and, in the studies published in human medicine journals that tested drugs on dogs, the syndrome was induced in different ways, surgically or pharmacologically. Different pathologies that cause $\mathrm{CHF}$, such as the surgical procedure or the drug used to induce a low cardiac output, were not particularly taken into consideration.

Studies published in veterinary journals were only a few in the 1970s; however, over the years, their number increased until they were more than the studies published in human journals where the dog was used as a laboratory animal. Furthermore, regarding the studies published in veterinary medicine journals, it should be noted that the experimental studies (DMD) are fewer than the studies carried out on dogs with spontaneous pathology.

As can be seen from Figure 2, over the years, the types of studies have increased considerably in veterinary medicine, and reviews have always had an increasing trend over the five decades. It is important to remember that reviews should be published every 4-5 years as they are useful to understand the direction of the research; however, systematic reviews are restricted in veterinary medicine. Cohort studies are not very numerous in veterinary medicine due to their high cost, long duration, and potential numerous losses of subjects during the study. Over the past two decades, randomized controlled trials have become more and more numerous; they have the advantage of selecting a group of patients through defined criteria, administering the treatment randomly, and thus reducing bias.

The databases chosen for the research of the studies to be included in this narrative review were PubMed, Google Scholar, and Embase. PubMed was the database that provided the greatest number of studies and, in particular, the oldest ones. It is a very wide database and, thanks to the use of Mesh terms and Boolean operators, allows the researcher to identify the most pertinent studies easily and quickly. Google Scholar is a very intuitive and easy-to-use database. The results obtained are conspicuous as there are also books, citations, meetings, and symposiums; however, it is more generic compared to PubMed, and sometimes some results are irrelevant. It is important to remember that Google Scholar is the only free access database among these three; not all information may be accessible without an institutional account, but it allows anyone to search. Embase is a database that allows precise searches, although fewer old studies have been found compared to PubMed.

This review is a narrative review (NR) or non-systematic review: NRs are aimed at identifying and summarizing what has been previously published, avoiding duplications, and seeking new study areas that have not yet been addressed. An NR does not have the strict rules of a systematic review; therefore, an NR potentially leads to biases because of subjectivity in the study selection [5].

\section{Conclusions}

The treatments of chronic CHF secondary to MMVD in dogs have considerably changed in the last fifty years, and some drugs have changed their intended use, such as digitalis glycosides and spironolactone. In the 1970s, the research and the literature were human medicine oriented, CHF in dogs was usually experimentally induced, and dogs were considered experimental animals. Later, the health and wellness of dogs have become primary endpoints; therefore, the research has been carried out on dogs as patients, and the therapy of CHF secondary to MMVD has been studied mainly on the spontaneous disease. This NR has been aimed at identifying and summarizing what has been previously 
published, avoiding duplications, with the intent to be a useful tool for the clinicians approaching this topic.

\begin{abstract}
Author Contributions: Conceptualization, P.G.B., M.B. and V.Z.; methodology, V.Z. and M.B.; software, V.Z.; validation, P.G.B., M.B., V.Z., C.L., A.G. and S.G.; formal analysis, V.Z.; investigation, V.Z. and M.B.; resources, P.G.B.; data curation, V.Z. and M.B.; writing-original draft preparation, M.B., V.Z. and P.G.B.; writing-review and editing, M.B., V.Z., P.G.B., C.L., A.G. and S.G.; visualization, M.B., V.Z. and P.G.B.; supervision, P.G.B.; project administration, P.G.B. and M.B.; funding acquisition, M.B. All authors have read and agreed to the published version of the manuscript.
\end{abstract}

Funding: This research received no external funding.

Institutional Review Board Statement: Not applicable.

Conflicts of Interest: The authors declare no conflict of interest.

\title{
References
}

1. Fox, P.R. Pathology of myxomatous mitral valve disease in the dog. J. Vet. Cardiol. 2012, 14, 103-126. [CrossRef]

2. Atkins, C.; Bonagura, J.; Ettinger, S.; Fox, P.; Gordon, S.; Haggstrom, J.; Stepien, R. Guidelines for the Diagnosis and Treatment of Canine Chronic Valvular Heart Disease. J. Vet. Intern. Med. 2009, 23, 1142-1150. [CrossRef]

3. Keene, B.W.; Atkins, C.E.; Bonagura, J.D.; Fox, P.R.; Häggström, J.; Luis Fuentes, V.; Oyama, M.A.; Rush, J.E.; Stepien, R.; Uechi, M. ACVIM consensus guidelines for the diagnosis and treatment of myxomatous mitral valve disease in dogs. J. Vet. Intern. Med. 2019, 33, 1127-1140. [CrossRef] [PubMed]

4. Yancy, C.W.; Jessup, M.; Bozkurt, B.; Butler, J.; Casey, D.E., Jr.; Drazner, M.H.; Fonarow, G.C.; Geraci, S.A.; Horwich, T.; Januzzi, J.L.; et al. 2013 ACCF/AHA Guideline for the Management of Heart Failure. JACC 2013, 62, 147-239. [CrossRef]

5. Ferrari, R. Writing narrative style literature reviews. Med. Writ. 2015, 24, 230-235. [CrossRef]

6. Ranganathan, P.; Aggarwal, R. Study designs: Part 1-An overview and classification. Perspect. Clin. Res. 2018, 9, 184-186. [PubMed]

7. Röhrig, B.; Du Prel, J.B.; Wachtlin, D.; Blettner, M. Types of study in medical research: Part 3 of a series on evaluation of scientific publications. Dtsch. Arztebl. Int. 2009, 106, 262-268.

8. Bottarelli, E.; Ostanello, F. Compiti e scopi dell'epidemiologia. In Epidemiologia-Teoria ed Esempi di Medicina Veterinaria, 1st ed.; Edagricole: Milan, Italy, 2011; pp. 29-75.

9. Kumar, B.; Hood, W.B., Jr.; Joison, J.; Gilmour, D.P.; Norman, J.C.; Abelmann, W.H. Experimental myocardial infarction: VI Efficacy and toxicity of digitalis in acute and healing phase in intact conscious dogs. J. Clin. Investig. 1970, 49, 358-364. [CrossRef]

10. Vatner, S.F.; Higgins, C.B.; Franklin, D.; Braunwald, E. Effects of a Digitalis Glycoside on Coronary and Systemic Dynamics in Conscious Dogs. Circ. Res. 1971, 28, 470-479. [CrossRef]

11. Higgins, C.B.; Vatner, S.F.; Braunwald, E. Regional Hemodynamic Effects of a Digitalis Glycoside in the Conscious Dog with and without Experimental Heart Failure. Circ. Res. 1972, 30, 406-417. [CrossRef] [PubMed]

12. Sakai, K.; Sugano, S.; Isono, C. Effects of oxyfedrine and ouabain on the heart-lung preparation of the dog. Naunyn Schmiedebergs Arch. Pharmacol. 1973, 277, 89-102. [CrossRef] [PubMed]

13. Vatner, S.F.; Higgins, C.B.; Braunwald, E. Effects of norepinephrine on coronary circulation and left ventricular dynamics in the conscious dog. Circ. Res. 1974, 34, 812-823. [CrossRef]

14. Vatner, S.F.; Mc Ritchie, R.J.; Maroko, P.R.; Patrick, T.A.; Braunwald, E. Effects of Catecholamines, Exercise, and Nitroglycerin on the Normal and Ischemic Myocardium in Conscious Dogs. J. Clin. Investig. 1974, 54, 563-575. [CrossRef]

15. Vatner, S.F.; Mc Ritchie, R.J.; Braunwald, E. Effects of Dobutamine on Left Ventricular Performance, Coronary Dynamics, and Distribution of Cardiac Output in Conscious Dogs. J. Clin. Investig. 1974, 53, 1265-1273. [CrossRef]

16. Kim, Y.I.; Noble, R.J.; Zipes, D.P. Dissociation of the inotropic effect of digitalis from its effect on atrioventricular conduction. Am. J. Cardiol. 1975, 36, 459-467. [CrossRef]

17. Cummings, J.R.; Beaulieu, G. Positive inotropic and antiarrhythmic actions of actodigin in dogs (1). Arch. Int. Pharmacodyn. Ther. 1977, 228, 92-98. [PubMed]

18. Kirk, E.S.; Lejemtel, T.H.; Nelson, G.R.; Sonnenblick, E.H. Mechanisms of beneficial effects of vasodilators and inotropic stimulation in the experimental failing ischemic heart. Am. J. Med. 1978, 65, 189-196. [CrossRef]

19. O'Keeffe, B.; Hayler, A.M.; Holt, D.W.; Medd, R.K. Cardiac consequences and treatment intoxication: Experimental evaluation of disopyramide in dogs. Cardiovasc. Res. 1979, 13, 630-634. [CrossRef]

20. Atwell, R.B. The use of alpha blockade in the treatment of congestive heart failure associated with dirofilariasis and mitral valvular incompetence. Vet. Rec. 1979, 104, 114-116. [CrossRef]

21. Ettinger, S.J.; Suter, P.F. Digitalis and the Cardiac Glicosides. In Canine Cardiology, 1st ed.; W.B. Saunders Company: Toronto, ON, Canada, 1970; pp. 224-261.

22. Ek, L.; Björkman, J.A.; Carlsson, E.; Johansson, B. The haemodynamic effects of intravenous prenalterol and ouabain in conscious dogs. Acta Med. Scand. Suppl. 1982, 659, 39-52. [CrossRef] 
23. Engler, R.; Pouleur, H.; Link, J.; Printz, M.; Covell, J.W. Changes in control of renin release in congestive heart failure in dogs: Response to acute and chronic vasodilator therapy. Clin. Exp. Hypertens A 1982, 4, 639-659. [CrossRef]

24. O'Rourke, R.A.; Badke, F.R.; Forst, D. Comparative hemodynamic effects of digoxin vs nitroprusside in conscious dogs with aortocaval fistula-induced chronic left ventricular volume overload and normal systolic performance. Am. Heart J. 1982, 103, 489-497. [CrossRef]

25. Satoh, K.; Kawada, M.; Taira, N. Improvement by trapidilod cardiac function of the dog heart-lung preparation depressed by pentobarbital. Jpn. Heart J. 1983, 24, 399-405. [CrossRef]

26. Pouleur, H.; Rousseau, M.F.; van Mechelen, H.; Roncoroni, L.; Ries, A.; Charlier, A.A. Cardiovascular effects of AR-L115 BS in conscious dogs with and without chronic congestive heart failure. J. Cardiovasc. Pharmacol. 1982, 4, 409-418. [CrossRef]

27. Alousi, A.A.; Canter, J.M.; Montenaro, M.J.; Fort, D.J.; Ferrari, R.A. Cardiotonic activity of milrinone, a new and potent cardiac bipyridine, on the normal and failing heart of experimental animals. J. Cardiovasc. Pharmacol. 1983, 5, 792-803. [CrossRef]

28. Carmines, P.K.; Rosivall, L.; Till, M.F.; Navar, L.G. Renal hemodynamic effects of captopril in anesthetized sodium-restricted dogs. Relative contributions of prostaglandin stimulation and suppressed angiotensin activity. Ren. Physiol. 1983, 6, 281-287. [PubMed]

29. Fennell, W.H.; Taylor, A.A.; Young, J.B.; Brandon, T.A.; Ginos, J.Z.; Goldberg, L.I.; Mitchell, J.R. Propylbutyldopamine: Hemodynamic Effects in Conscious Dogs, Normal Human Volunteers and Patients with Heart Failure. Circulation 1983, 67, 829-836. [CrossRef] [PubMed]

30. Leddy, C.L.; Wilen, M.; Franciosa, J.A. Effects of a new angiotensin converting enzyme inhibitor, enalapril, in acute and chronic left ventricular failure in dogs. J. Clin. Pharmacol. 1983, 23, 189-198. [CrossRef]

31. MacCannell, K.L.; Giraud, G.D.; Hamilton, P.L.; Groves, G. Haemodynamic responses to dopamine and dobutamine infusions as a function of duration of infusion. Pharmacology 1983, 26, 29-39. [CrossRef]

32. Morita, T.; Satoh, K.; Taira, N. Improvement of cardiac performance by AR-L 115 BS, a new cardiotonic drug, in the experimental failing dog heart. Jpn. Heart J. 1984, 25, 439-445. [CrossRef] [PubMed]

33. Engler, R.L.; Freeman, G.L.; Covell, J.W. Regional venous return: Nitroprusside effect in normal and chronically congested dogs. Am. J. Physiol. 1983, 245, 814-823. [CrossRef] [PubMed]

34. Pastelìn, G.; Mendez, R. Cardiac effects of six actodigin (AY-22,241)-related semisynthetic glycosides. Life Sci. 1983, 32, 1905-1909. [CrossRef]

35. Pastelin, G.; Mendez, R.; Kabela, E.; Farah, A. The search for a digitalis substitute II milrinone (Win 47203). Its action on the heart-lung preparation of the dog. Life Sci. 1983, 33, 1787-1796. [CrossRef]

36. Porter, C.B.; Walsh, R.A.; Badke, F.R.; O'Rourke, R.A. Differential effects of diltiazem and nitroprusside on left ventricular function in experimental chronic volume overload. Circulation 1983, 68, 685-692. [CrossRef]

37. Pouleur, H.; Engler, R.L.; Link, J.; Printz, M.P.; Covell, J.W. Changes in plasma renin activity and haemodynamics during vasodilator therapy in conscious dogs with myocardial infarction or chronic volume overload. Eur. J. Clin. Investig. 1983, 13, 331-338. [CrossRef]

38. Pouleur, H.; Marechal, G.; Balasim, H.; Van Mechelen, H.; Ries, A.; Rousseau, M.F.; Charlier, A.A. Effects of dobutamine and sulmazol (AR-L115 BS) on myocardial metabolism and coronary, femoral, and renal blood flows: A comparative study in normal dogs and in dogs with chronic volume overload. J. Cardiovasc. Pharmacol. 1983, 5, 861-867. [CrossRef]

39. Prasad, K.; O'Neil, C.L.; Bharadwaj, B. Effects of chronic digoxin treatment on cardiac function, electrolytes, and sarcolemmal ATPase in the canine failing heart due to chronic mitral regurgitation. Am. Heart J. 1984, 108, 1487-1494. [CrossRef]

40. Riegger, G.A.; Liebau, G.; Holzschuh, M.; Witkowski, D.; Steilner, H.; Kochsiek, K. Role of the renin-angiotensin system in the development of congestive heart failure in the dog as assessed by chronic converting-enzyme blockade. Am. J. Cardiol. 1984, 53, 614-618. [CrossRef]

41. Braunwald, E. Effects of Digitalis on the Normal and the Failing Heart. J. Am. Coll. Cardiol. 1985, 5, 51-59. [CrossRef]

42. Kosugi, I.; Gonga, T.; Okada, K.; Tajimi, K.; Moriyasu, N.; Fukatsu, O. Effects of amrinone on hemodynamics, oxygen consumption and plasma catecholamine levels in anesthetized dogs. Masui 1985, 34, 429-433.

43. Nunoki, K.; Goto, T.; Satoh, K.; Taira, N. Improvement by denopamine (TA-064) of pentobarbital-induced cardiac failure in the dog heart-lung preparation. Heart Vessels 1985, 1, 216-219. [CrossRef] [PubMed]

44. Hori, M.; Inoue, M.; Tamai, J.; Koretsune, Y.; Kitakaze, M.; Iwai, K.; Ito, H.; Kitabatake, A.; Kamada, T. Cardiotonic activity of a new inotropic agent, 3,4-dihydro-6-[4-(3,4-dimethoxybenzoyl)-1-piperazinyl]-2(1H)-quinolinone (OPC-8212), in the dogs with and without b-blocker and Ca++ antagonist pretreatment. Jpn. Circ. J. 1986, 50, 37-44. [CrossRef]

45. Goto, T.; Nunoki, K.; Satoh, K.; Taira, N. Amelioration of heart failure by MDL 17043 and MDL 19205, novel positive inotropic drugs, in dog heart-lung preparations. Jpn. Heart J. 1985, 26, 1011-1018. [CrossRef]

46. Prasad, K.; O'Neil, C.L.; Bharadwaj, B. Effect of chronic prazosin treatment on the cardiac function and electrolytes in failing heart due to chronic mitral insufficiency. Can. J. Cardiol. 1985, 1, 107-112.

47. Prasad, K.; O'Neil, C.L.; Bharadwaj, B. Effect of prazosin treatment on the cardiac sarcolemmal ATPase in failing heart due to mitral insufficiency in dogs. Cardiovasc. Res. 1985, 19, 406-410. [CrossRef]

48. Weyl, J.D.; Snyder, R.W.; Hanson, R.C. Differential cardioprotective properties of the l- and d- enantiomers of bucindolol in a canine model of heart failure. Arch. Int. Pharmacodyn. Ther. 1985, 275, 4-12. 
49. Ikeo, T.; Nagao, T.; Murata, S.; Yabana, H.; Sato, M.; Nakajima, H. Cardiovascular effects of the new positive inotropic agent denopamine with special reference to species difference and the effect on failing heart. Arzneimittelforschung 1986, 36, 1063-1068. [PubMed]

50. Sonoki, H.; Uchida, Y.; Masuo, M.; Tomaru, T.; Katoh, A.; Sugimoto, T. Effects of forskolin on canine congestive heart failure. Nihon Yakurigaku Zasshi 1986, 88, 389-394. [CrossRef]

51. Petein, M.; Heppner, B.; Bache, R.J.; Cohn, J.N.; Pierpont, G.L. Hemodynamic and regional blood flow response to piroximone (MDL 19205) in dogs with congestive heart failure: A comparison with dobutamine. J. Pharmacol. Exp. Ther. 1987, 241, 956-960. [PubMed]

52. Goldberg, E.; Berdoff, R.; Spivack, G.; Haimowitz, A.; Tay, S. Evaluation of the vasodilator vs inotropic effect of milrinone using an animal model of left ventricular failure: Reversal of disopyramide depression of the myocardium with milrinone. Angiology 1987, 38, 657-662. [CrossRef]

53. Imagawa, J.; Nabata, H.; Sakai, K. Comparison of cardiovascular effects of SGB-1534 and prazosin, selective a-adrenoceptor antagonists, in anesthetized dogs. Jpn. J. Pharmacol. 1987, 44, 35-41. [CrossRef]

54. Satoh, K.; Nunoki, K.; Goto, T.; Hosono, M.; Hashimoto, H.; Sato, Y.; Taira, N. Improvement of pentobarbital-induced heart failure by MCL-154, a novel and potent cardiotonic agent, in the dog heart-lung preparation. Jpn. J. Pharmacol. 1988, 47, 189-195. [CrossRef]

55. Sonoki, H.; Uchida, Y.; Tomaru, T.; Sugimoto, T. Effects of prazosin, SGB-1534, dobutamine and isoproterenol on congestive heart failure in dogs. Nihon Yakurigaku Zasshi 1988, 92, 119-126. [CrossRef]

56. Hittinger, L.; Shannon, R.P.; Kohin, S.; Lader, A.S.; Manders, W.T.; Patrick, T.A.; Kelly, P.; Vatner, S.F. Isoproterenol-Induced Alterations in Myocardial Blood Flow, Systolic and Diastolic Function in Conscious Dogs With Heart Failure. Circulation 1989, 80, 658-668. [CrossRef] [PubMed]

57. Pouleur, H.; Hanet, C.; Schröder, E.; Col, J.; Van Mechelen, H.; Etienne, J.; Rousseau, M.F. Effects of pimobendan (UD-CG 115 BS) on left ventricular inotropic state in conscious dogs and in patients with heart failure. J. Cardiovasc. Pharmacol. 1989, 14, 18-22.

58. Sahashi, T.; Ito, H.; Nagata, K.; Hirose, I.; Wada, H.; Takai, K.; Hirakawa, S. Effects of ace inhibitor (captopril) on canine systemic capacitance vessels: A study with the measurement of mean circulatory pressure. Acta Sch. Med. Univ. Gifu 1989, 37, $1011-1023$.

59. Van Meel, J.C.; Diederen, W. Hemodynamic profile of the cardiotonic agent pimobendan. J. Cardiovasc. Pharmacol. 1989, 14, S1-S6.

60. Kittleson, M.D.; Hamlin, R.L. Hydralazine pharmacodynamics in the dog. Am. J. Vet. Res. 1983, 44, 1501-1505.

61. Hamlin, R.L.; Kittleson, M.D. Clinical experience with hydralazine for treatment of otherwise intractable cough in dogs with apparent left-side heart failure. J. Am. Vet. Med. Assoc. 1982, 180, 1327-1329. [PubMed]

62. Kittleson, M.D.; Johnson, L.E.; Oliver, N.B. Acute hemodynamic effects of hydralazine in dogs with chronic mitral regurgitation. J. Am. Vet. Med. Assoc. 1985, 187, 258-261.

63. Kittleson, M.D.; Pipers, F.S.; Knauer, K.W.; Keister, D.M.; Knowlen, G.G.; Miner, W.S. Echocardiographic and clinical effects of milrinone in dogs with myocardial failure. Am. J. Vet. Res. 1985, 46, 1659-1664. [PubMed]

64. Tobias, A.H.; Bland-van den Berg, P.; Kruse, M.M.; Tubbesing, U.H.; Berry, W.L. Serum digoxin concentrations in canine congestive heart failure. J. S. Afr. Vet. Assoc. 1989, 60, 11-14. [PubMed]

65. Staudacher, G. Individual glycoside therapy using serum concentration determination in canine heart failure. Dtsch. Tierarztl. Wochenschr. 1989, 96, 308-310.

66. Barrett, J.A.; Woltmann, R.F.; Swillo, R.S.; Kasiewski, C.; Faith, W.C.; Campbell, H.F.; Perrone, M.H. Pharmacology of RG W-2938: A cardiotonic agent with vasodilator activity. J. Cardiovasc. Pharmacol. 1990, 16, 537-545. [CrossRef]

67. Blackford, L.W.; Golden, A.L.; Bright, J.M.; Bright, R.M.; Gompf, R.E. Captopril provides sustained hemodynamic benefits in dogs with experimentally induced mitral regurgitation. Vet. Surg. 1990, 19, 237-242. [CrossRef]

68. Carlyle, P.F.; Cohn, J.N. Systemic and regional hemodynamic effects of alpha-adrenoceptor blockade in chronic left ventricular dysfunction in the conscious dog. Am. Heart J. 1990, 120, 619-624. [CrossRef]

69. Elsner, D.; Kromer, E.P.; Riegger, A.J. Hemodynamic, hormonal, and renal effects of the prostacyclin analogue iloprost in conscious dogs with and without heart failure. J. Cardiovasc. Pharmacol. 1990, 16, 601-608. [CrossRef]

70. Holtz, J.; Munzel, T.; Sommer, O.; Bassenge, E. Converting enzyme inhibition by enalapril in experimental heart failure. Nephron 1990, 55, 73-76. [CrossRef] [PubMed]

71. Lavine, S.J.; Campbell, C.A.; Held, A.C.; Johnson, V. Effect of inotropic and vasodilator therapy on left ventricular diastolic filling in dogs with severe left ventricular dysfunction. J. Am. Coll. Cardiol. 1990, 15, 1165-1172. [CrossRef]

72. Riegger, G.A.; Elsner, D.; Forssmann, W.G.; Kromer, E.P. Effects of ANP-(95-126) in dogs before and after induction of heart failure. Am. J. Physiol. 1990, 259, 1643-1648. [CrossRef] [PubMed]

73. Gosgnach, M.; Gérard, J.L.; Berdeaux, A.; Giudicelli, J.F. Compared peripheral vascular responses to intravenous and intra-arterial administrations of positive inotropic agents in conscious dogs. Fundam. Clin. Pharmacol. 1991, 5, 709-718. [CrossRef]

74. Ichihara, K.; Abiko, Y. The effect of pimobendan on myocardial mechanical function and metabolism in dogs: Comparison with dobutamine. J. Pharm. Pharmacol. 1991, 43, 583-588. [CrossRef] [PubMed]

75. Riegger, A.J. ACE inhibition: Mechanisms of cardioprotection in chronic experimental heart failure. Klin. Wochenschr. 1991, 69, 20-23. [PubMed]

76. Dogterom, P.; Zbinden, G.; Reznik, G.K. Cardiotoxicity of vasodilators and positive inotropic/vasodilating drugs in dogs: An overview. Crit. Rev. Toxicol. 1992, 22, 203-241. [CrossRef] 
77. Elsner, D.; Müntze, A.; Kromer, E.P.; Riegger, G.A. Prostaglandin E2 in dogs with heart failure: Hemodynamic, hormonal, and renal effects. J. Cardiovasc. Pharmacol. 1992, 20, 547-553. [CrossRef] [PubMed]

78. Elsner, D.; Müntze, A.; Kromer, E.P.; Riegger, G.A. Prostaglandin I2 versus prostaglandin E2 in dogs with and without low cardiac output. Differential effects on renal function. Am. J. Hypertens 1992, 5, 175-179. [CrossRef] [PubMed]

79. Sudo, Y.; Takai, M.; Esumi, K. Improved heart failure protection by FK664, a novel positive inotropic agent, in dog heart-lung preparations. Life Sci. 1992, 51, 41-46. [CrossRef]

80. Brands, M.W.; Alonso-Galicia, M.; Mizelle, H.L.; Montani, J.P.; Hildebrandt, D.A.; Hall, J.E. Chronic angiotensin-convertingenzyme inhibition improves cardiac output and fluid balance during heart failure. Am. J. Physiol. 1993, 264, 414-422. [CrossRef]

81. Pagel, P.S.; Hettrick, D.A.; Warltier, D.C. Amrinone enhances myocardial contractility and improves left ventricular diastolic function in conscious and anesthetized chronically instrumented dogs. Anesthesiology 1993, 79, 753-765. [CrossRef]

82. Sabbah, H.N.; Levine, T.B.; Gheorghiade, M.; Kono, T.; Goldstein, S. Hemodynamic response of a canine model of chronic heart failure to intravenous dobutamine, nitroprusside, enalaprilat, and digoxin. Cardiovasc. Drugs Ther. 1993, 7, 349-356. [CrossRef]

83. Satoh, K.; Satoh, Y.; Imagawa, J.; Taira, N. Improvement of cardiac performance by pimobendan, a new cardiotonic drug, in the experimental failing dog heart. Jpn. Heart J. 1993, 34, 213-219. [CrossRef] [PubMed]

84. Seymour, A.A.; Asaad, M.M.; Lanoce, V.M.; Langenbacher, K.M.; Fennell, S.A.; Rogers, W.L. Systemic hemodynamics, renal function and hormonal levels during inhibition of neutral endopeptidase 3.4.24.11 and angiotensin-converting enzyme in conscious dogs with pacing-induced heart failure. J. Pharmacol. Exp. Ther. 1993, 266, 872-883. [PubMed]

85. McDonald, K.M.; Francis, G.S.; Matthews, J.; Hunter, D.; Cohn, J.N. Long-Term Oral Nitrate Therapy Prevents Chronic Ventricular Remodeling in the Dog. J. Am. Coll. Cardiol. 1993, 21, 514-522. [CrossRef]

86. Moe, G.W.; Montgomery, G.; Howard, R.J.; Grima, E.A.; Armstrong, P.W. Left ventricular myocardial blood flow, metabolism, and effects of treatment with enalapril: Further insights into the mechanisms of canine experimental pacing-induced heart failure. J. Lab. Clin. Med. 1993, 121, 294-301.

87. Wang, J.; Zhao, G.; Shen, W.; Ochoa, M.; Moore, D.; Hubbard, J.W.; Hintze, T.H. Effects of an orally active NO-releasing agent, CAS 936, and its active metabolite, 3754, on cardiac and coronary dynamics in normal conscious dogs and after pacing-induced heart failure. J. Cardiovasc. Pharmacol. 1993, 22, 51-58. [CrossRef]

88. Asanoi, H.; Ishizaka, S.; Kameyama, T.; Ishise, H.; Sasayama, S. Disparate inotropic and lusitropic responses to pimobendan in conscious dogs with tachycardia-induced heart failure. J. Cardiovasc. Pharmacol. 1994, 23, 268-274. [CrossRef] [PubMed]

89. Forster, C.; Naik, G.O.; Larosa, G. Myocardial beta-adrenoceptors in pacing-induced heart failure: Regulation by enalapril? Can. J. Physiol. Pharmacol. 1994, 72, 667-672. [CrossRef] [PubMed]

90. Himura, Y.; Liang, C.S.; Delehanty, J.M.; Hood, W.B., Jr. Nitroprusside infusion improves arterial baroreflex control of heart rate in dogs with chronic congestive heart failure. J. Cardiovasc. Pharmacol. 1994, 24, 702-706. [CrossRef]

91. Ishimori, T.; Gotanda, K.; Sasaki, T.; Shinbo, A.; Asano, H.; Miyazawa, K.; Miyasaka, K. Cardiac effects of the novel pyridazinone derivative 6-[4-[2-[3-(5-chloro-2-cyanophenoxy)-2-hydroxypropylamino]-2-methylpropylamino]phenyl]-4,5-dihydro5-methyl-3(2H) pyridazinone monoethyl maleate and its metabolite in isolated heart preparations of guinea pigs and dogs. Arzneimittelforschung 1994, 44, 583-588.

92. Levett, J.M.; Marinelli, C.C.; Lund, D.D.; Pardini, B.J.; Nader, S.; Scott, B.D.; Augelli, N.V.; Kerber, R.E.; Schmid, P.G., Jr. Effects of beta-blockade on neurohumoral responses and neurochemical markers in pacing-induced heart failure. Am. J. Physiol. 1994, 266, 468-475. [CrossRef]

93. Ogilvie, R.I.; Zborowska-Sluis, D. Effect of captopril treatment on total and central vascular capacitance in dogs with chronic heart failure. J. Cardiovasc. Pharmacol. 1994, 24, 358-364. [CrossRef] [PubMed]

94. Kono, T.; Sabbah, H.N.; Rosman, H.; Shimoyama, H.; Alam, M.; Goldstein, S. Divergent effects of intravenous dobutamine and nitroprusside on left atrial contribution to ventricular filling in dogs with chronic heart failure. Am. Heart J. 1994, 127, 874-880. [CrossRef]

95. Pagel, P.S.; Harkin, C.P.; Hettrick, D.A.; Warltier, D.C. Levosimendan (OR-1259), a myofilament calcium sensitizer, enhances myocardial contractility but does not alter isovolumic relaxation in conscious and anesthetized dogs. Anesthesiology 1994, 81, 974-987. [CrossRef] [PubMed]

96. Tsutsui, H.; Spinale, F.G.; Nagatsu, M.; Schmid, P.G.; Ishihara, K.; DeFreyte, G.; Cooper, G.; Carabello, B.A. Effects of Chronic B-Adrenergic Blockade on the Left Ventricular and Cardiocyte Abnormalities of Chronic Canine Mitral Regurgitation. J. Clin. Investig. 1994, 93, 2639-2648. [CrossRef] [PubMed]

97. Sabbah, H.N.; Shimoyama, H.; Kono, T.; Gupta, R.C.; Sharov, V.G.; Scicli, G.; Levine, T.B.; Goldstein, S. Effects of Long-term Monotherapy with Enalapril, Metoprolol, and Digoxin on the Progression of Left Ventricular Dysfunction and Dilation in Dogs With Reduced Ejection Fraction. Circulation 1994, 89, 2852-2859. [CrossRef]

98. Evans, M.A.; Burnett, J.C., Jr.; Redfield, M.M. Effect of Low Dose Aspirin on Cardiorenal Function and Acute Hemodynamic Response to Enalaprilat in a Canine Model of Severe Heart Failure. J. Am. Coll. Cardiol. 1995, 25, 1445-1450. [CrossRef]

99. Harkin, C.P.; Pagel, P.S.; Tessmer, J.P.; Warltier, D.C. Systemic and coronary hemodynamic actions and left ventricular functional effects of levosimendan in conscious dogs. J. Cardiovasc. Pharmacol. 1995, 26, 179-188. [CrossRef] [PubMed]

100. Ogilvie, R.I.; Zborowska-Sluis, D. Effect of perindopril in pacing-induced canine models of acute and chronic heart failure. Can. J. Cardiol. 1995, 11, 934-940. 
101. Murakami, M.; Suzuki, H.; Naitoh, M.; Matsumoto, A.; Kageyama, Y.; Tsujimoto, G.; Saruta, T. Blockade of the renin-angiotensin system in heart failure in conscious dogs. J. Hypertens. 1995, 13, 1405-1412. [CrossRef]

102. Shimoyama, H.; Sabbah, H.N.; Rosman, H.; Alam, M.; Goldstein, S. Effect of B-blockade on left atrial contribution to ventricular filling in dogs with moderate heart failure. Am. Heart J. 1996, 131, 772-777. [CrossRef]

103. Shimoyama, H.; Sabbah, H.N.; Rosman, H.; Kono, T.; Alam, M.; Goldstein, S. Effects of Long-Term Therapy with Enalapril on Severity of Functional Mitral Regurgitation in Dogs with Moderate Heart Failure. J. Am. Coll. Cardiol. 1995, 25, 768-772. [CrossRef]

104. Kinugawa, T.; Dibner-Dunlap, M.E. Altered vagal and sympathetic control of heart rate in left ventricular dysfunction and heart failure. Am. J. Physiol. 1995, 268, 310-316. [CrossRef] [PubMed]

105. Fujiki, H.; Mori, T.; Tominaga, M. Effects of OPC-18790 on hemodynamics and the $\beta$-adrenergic receptor pathway during long-term infusion in conscious dogs: A comparison to dobutamine. Prev. Manag. Congest. Heart Fail. 1996, 2, 12-20.

106. Itoh, S.; Mori, T.; Fujiki, H.; Tominaga, M. Effects of toborinone on myocardial oxygen consumption in pacing-induced heart failure dogs. Arzneimittelforschung 1996, 46, 1105-1109.

107. McConnell, P.I.; Wang, W.; Zucker, I.H. Effects of an orally effective endothelin-A receptor antagonist in dogs with pacing-induced heart failure. Neb. Med. J. 1996, 81, 349-355.

108. McMahon, W.S.; Holzgrefe, H.H.; Walker, J.D.; Mukherjee, R.; Arthur, S.R.; Cavallo, M.J.; Child, M.J.; Spinale, F.G. Cellular Basis for Improved Left Ventricular Pump Function After Digoxin Therapy in Experimental Left Ventricular Failure. J. Am. Coll. Cardiol. 1996, 28, 495-505. [CrossRef]

109. Pagel, P.S.; Hettrick, D.A.; Warltier, D.C. Influence of levosimendan, pimobendan, and milrinone on the regional distribution of cardiac output in anaesthetized dogs. Br. J. Pharmacol. 1996, 119, 609-615. [CrossRef] [PubMed]

110. Pagel, P.S.; Hettrick, D.A.; Warltier, D.C. Comparison of the effects of levosimendan, pimobendan, and milrinone on canine left ventricular-arterial coupling and mechanical efficiency. Basic Res. Cardiol. 1996, 91, 296-307. [CrossRef]

111. Shimoyama, H.; Sabbah, H.N.; Borzak, S.; Tanimura, M.; Shevlyagin, S.; Scicli, G.; Goldstein, S. Short-term hemodynamic effects of endothelin receptor blockade in dogs with chronic heart failure. Circulation 1996, 94, 779-784. [CrossRef]

112. Nozaki, J.; Kitahata, H.; Tanaka, K.; Kawahito, S.; Oshita, S. The effects of acute normovolemic hemodilution on left ventricular systolic and diastolic function in the absence or presence of beta-adrenergic blockade in dogs. Anest. Analg. 2002, 94, 1120-1126. [CrossRef]

113. Shannon, R.P.; Friedrich, S.; Mathier, M.; Knight, D.R. Effects of renin inhibition compared to angiotensin converting enzyme inhibition in conscious dogs with pacing-induced heart failure. Cardiovasc. Res. 1997, 34, 464-472. [CrossRef]

114. Teramura, S.; Yamakado, T.; Maeda, M.; Nakano, T. Effects of MCI-154, a calcium sensitizer, on left ventricular systolic and diastolic function in pacing-induced heart failure in the dog. Circulation 1997, 95, 732-739. [CrossRef]

115. Dell'Italia, L.J.; Balcells, E.; Meng, Q.C.; Su, X.; Schultz, D.; Bishop, S.P.; Machida, N.; Straeter-Knowlen, I.M.; Hankes, G.H.; Dillon, R.; et al. Volume-overload cardiac hypertrophy is unaffected by ACE inhibitor treatment in dogs. Am. J. Physiol. 1997, 273, 961-970. [CrossRef] [PubMed]

116. King, J.N.; Maurer, M.; Morrison, C.A.; Mauron, C.; Kaiser, G. Pharmacokinetics of the angiotensin-converting-enzyme inhibitor, benazepril, and its active metabolite, benazeprilat, in dog. Xenobiotica 1997, 27, 819-829. [CrossRef] [PubMed]

117. Stanley, W.C.; Li, B.; Bonhaus, D.W.; Johnson, L.G.; Lee, K.; Porter, S.; Walker, K.; Martinez, G.; Eglen, R.M.; Whiting, R.L.; et al. Catecholamine modulatory effects of nepicastat (RS-25560-197), a novel, potent and selective inhibitor of dopamine-b-hydroxylase. Br. J. Pharmacol. 1997, 121, 1803-1809. [CrossRef] [PubMed]

118. Ohte, N.; Cheng, C.P.; Suzuki, M.; Little, W.C. The Cardiac Effects of Pimobendan (But Not Amrinone) Are Preserved at Rest and During Exercise in Conscious Dogs with Pacing-Induced Heart Failure. J. Pharmacol. Exp. Ther. 1997, $282,23-31$.

119. Araki, S.; Uematsu, T.; Nagashima, S.; Matsuzaki, T.; Gotanda, K.; Ochiai, H.; Hashimoto, H.; Nakashima, M. Cardiac and Hemodynamic Effects of TZC-5665, a Novel Pyridazinone Derivative, and Its Metabolite in Humans and Dogs. Gen. Pharmacol. 1997, 28, 545-553. [CrossRef]

120. Wada, A.; Tsutamoto, T.; Fukai, D.; Ohnishi, M.; Maeda, K.; Hisanaga, T.; Maeda, Y.; Matsuda, Y.; Kinoshita, M. Comparison of the Effects of Selective Endothelin ETA and ETB Receptor Antagonists in Congestive Heart Failure. J. Am. Coll. Cardiol. 1997, 30, 1385-1392. [CrossRef]

121. Goussev, A.; Sharov, V.G.; Shimoyama, H.; Tanimura, M.; Lesch, M.; Goldstein, S.; Sabbah, H.N. Effects of ACE inhibition on cardiomyocyte apoptosis in dogs with heart failure. Am. J. Physiol. 1998, 275, 626-631. [CrossRef]

122. Panchal, A.R.; Stanley, W.C.; Kerner, J.; Sabbah, H.N. Beta-Receptor Blockade Decreases Carnitine Palmitoyl Transferase I Activity in Dogs with Heart Failure. J. Card. Fail. 1998, 4, 121-126. [CrossRef]

123. Lai, L.P.; Raju, V.S.; Delehanty, J.M.; Yatani, A.; Liang, C.S. Altered Sarcoplasmic Reticulum Ca2+ ATPase Gene Expression in Congestive Heart Failure: Effect of Chronic Norepinephrine Infusion. J. Mol. Cell. Cardiol. 1998, 30, 175-185. [CrossRef]

124. Ohnishi, M.; Wada, A.; Tsutamoto, T.; Fukai, D.; Kinoshita, M. Comparison of the acute effects of a selective endothelin ET-a and a mixed ET-a /ET-b receptor antagonist in heart failure. Cardiovasc. Res. 1998, 39, 617-624. [CrossRef]

125. Ohnishi, M.; Wada, A.; Fukai, D.; Sawaki, M.; Maeda, Y.; Kinoshita, M. Chronic effects of a novel, orally active endothelin receptor antagonist, T-0201, in dogs with congestive heart failure. J. Cardiovasc. Pharmacol. 1998, 31, 236-238. [CrossRef]

126. Ogilvie, R.I.; Zborowska-Sluis, D. Captopril and angiotensin II receptor antagonist therapy in a pacing model of heart failure. Can. J. Cardiol. 1998, 14, 1025-1033. 
127. Moe, G.W.; Albernaz, A.; Naik, G.O.; Kirchengast, M.; Stewart, D.J. Beneficial effects of long-term selective endothelin type A receptor blockade in canine experimental heart failure. Cardiovasc. Res. 1998, 39, 571-579. [CrossRef]

128. Yi, G.H.; Burkhoff, D.; Zhang, H.; Zhu, S.M.; Zwas, D.; Wang, J. Hemodynamic Effects of a Calcium Channel Promoter, BAY y 5959, are Preserved after Chronic Administration in Ischemic Heart Failure in Conscious Dogs. J. Pharmacol. Exp. Ther. 1998, 286, 760-766.

129. Borgeson, D.D.; Grantham, J.A.; Williamson, E.E.; Luchner, A.; Redfield, M.M.; Opgenorth, T.J.; Burnett, J.C., Jr. Chronic Oral Endothelin Type A Receptor Antagonism in Experimental Heart Failure. Hypertension 1998, 31, 766-770. [CrossRef]

130. Amati, B.; Littlewood, T.D.; Evan, G.I.; Land, H. The c-Myc protein induces cell cycle progression and apoptosis through dimerization with Max. EMBO J. 1993, 12, 5083-5087. [CrossRef] [PubMed]

131. Shen, Y.T.; Woltmann, R.F.; Appleby, S.; Prahalada, S.; Krause, S.M.; Kivilghn, S.D.; Johnson, R.G.; Siegl, P.K.; Lynch, J.J. Lack of beneficial effects of growth hormone treatment in conscious dogs during development of heart failure. Am. J. Physiol. 1998, 274, 456-466. [CrossRef] [PubMed]

132. Todaka, K.; Wang, J.; Yi, G.H.; Gu, A.; Zhu, S.M.; Zhang, H.; Burkhoff, D. Effect of BAY y 5959 on myocardial function and metabolism in normal and failing hearts. Am. J. Physiol. 1998, 274, 1560-1568. [CrossRef]

133. Kovacevic, A. Some drugs in the therapy of cardiac failure of dogs and cats. Farm. Glas. 1999, 55, $235-238$.

134. Straeter-Knowlen, I.M.; Dell'Italia, L.J.; Dai, J.; Hankes, G.H.; Dillon, A.R.; Cartee, R.E.; Pohost, G.M.; Ku, D.D. ACE inhibitors in HF restore canine pulmonary endothelial function and ANG II vasoconstriction. Am. J. Physiol. 1999, 277, 1924-1930. [CrossRef] [PubMed]

135. Mital, S.; Loke, K.E.; Slater, J.P.; Addonizio, L.; Gersony, W.M.; Hintze, T.H. Synergy of Amlodipine and Angiotensin-Converting Enzyme Inhibitors in Regulating Myocardial Oxygen Consumption in Normal Canine and Failing Human Hearts. Am. J. Cardiol. 1999, 83, 92-98. [CrossRef]

136. Yatsu, T.; Tomura, Y.; Tahara, A.; Wada, K.; Kusayama, T.; Tsukada, J.; Tokioka, T.; Uchida, W.; Inagaki, O.; Iizumi, Y.; et al. Cardiovascular and renal effects of conivaptan hydrochloride (YM087), a vasopressin V1a and V2 receptor antagonist, in dogs with pacing-induced congestive heart failure. Eur. J. Pharmacol. 1999, 376, 239-246. [CrossRef]

137. Tanimura, M.; Sharov, V.G.; Shimoyama, H.; Mishima, T.; Levine, T.B.; Goldstein, S.; Sabbah, H.N. Effects of AT1-receptor blockade on progression of left ventricular dysfunction in dogs with heart failure. Am. J. Physiol. 1999, 276, 1385-1392. [CrossRef]

138. Zhang, X.; Recchia, F.A.; Zhang, X.; Recchia, F.A.; Bernstein, R.; Xu, X.; Nasjletti, A.; Hintze, T.H. Kinin-mediated coronary nitric oxide production contributes to the therapeutic action of angiotensin-converting enzyme and neutral endopeptidase inhibitors and amlodipine in the treatment in heart failure. J. Pharmacol. Exp. Ther. 1999, 288, 742-751.

139. Koch, J.; Pedersen, H.D.; Jensen, A.L.; Flagstad, A.; Poulsen, K.; Bie, P. Short term effects of acute inhibition of the angiotensinconverting enzyme on the renin-angiotensin system and plasma atrial natriuretic peptide in healthy dogs fed a low-sodium diet versus a normal-sodium diet. Zent. Vet. A 1994, 41, 121-127. [CrossRef] [PubMed]

140. Allworth, M.S.; Church, D.B.; Maddison, J.E.; Einstein, R.; Brennan, P.; Abdul Hussein, N.; Matthews, R. Effect of enalapril in dogs with pacing-induced heart failure. Am. J. Vet. Res. 1995, 56, 85-94.

141. King, J.N.; Mauron, C.; Kaiser, G. Pharmacokinetics of the active metabolite of benazepril, benazeprilat, and inhibition of plasma angiotensin-converting enzyme activity after single and repeated administrations to dogs. Am. J. Vet. Res. 1995, 56, 1620-1628. [PubMed]

142. Smal, J.; Haapala, O.; Marvola, M.; Kuusela, S.; Happonen, I. Prolonged-release hard gelatin capsules of furosemide for the treatment of dogs. J. Vet. Pharmacol. Ther. 1995, 18, 17-23. [CrossRef]

143. Hamlin, R.L.; Benitz, A.M.; Ericsson, G.F.; Cifelli, S.; Daurio, C.P. Effects of Enalapril on Exercise Tolerance and Longevity in Dogs with Heart Failure Produced by Iatrogenic Mitral Regurgitation. J. Vet. Intern. Med. 1996, 10, 85-87. [CrossRef]

144. Hamlin, R.L.; Nakayama, T. Comparison of Some Pharmacokinetic Parameters of 5 Angiotensin-Converting Enzyme Inhibitors in Normal Beagles. J. Vet. Intern. Med. 1998, 12, 93-95. [CrossRef]

145. Roudebush, P.; Allen, T.A.; Kuehn, N.F.; Magerkurth, J.H.; Bowers, T.L. The Effect of Combined Therapy with Captopril, Furosemide, and a Sodium-Restricted Diet on Serum Electrolyte Concentrations and Renal Function in Normal Dogs and Dogs with Congestive Heart Failure. J. Vet. Intern. Med. 1994, 8, 337-342. [CrossRef]

146. Morisse, B.; Kersten, U. Treatment of heart failure in dogs with ACe inhibitors: Comparison of quinapril and captopril. Tierarztl. Prax. 1995, 23, 489-496. [PubMed]

147. The COVE Study Group. Controlled Clinical Evaluation of Enalapril in Dogs with Heart Failure: Results of the Cooperative Veterinary Enalapril Study Group. J. Vet. Intern. Med. 1995, 9, 243-252. [CrossRef] [PubMed]

148. The IMPROVE Study Group. Acute and Short-Term Hemodynamic, Echocardiographic, and Clinical Effects of Enalapril Maleate in Dogs with Naturally Acquired Heart Failure: Results of the Invasive Multicenter PROspective Veterinary Evaluation of Enalapril Study. J. Vet. Intern. Med. 1995, 9, 234-242. [CrossRef]

149. DeFrancesco, T.C.; Atkins, C.E.; Keene, B.W. Myocardial infarction complicating management of congestive heart failure in a dog. J. Am. Anim. Hosp. Assoc. 1996, 32, 68-72. [CrossRef]

150. Häggström, J.; Hansson, K.; Karlberg, B.E.; Kvart, C.; Madej, A.; Olsson, K. Effects of long-term treatment with enalapril or hydralazine on the renin-angiotensin-aldosterone system and fluid balance in dogs with naturally acquired mitral valve regurgitation. Am. J. Vet. Res. 1996, 57, 1645-1652. [PubMed] 
151. Hofmann, S.; Kersten, U. The effectiveness and tolerance of ramipril in comparison to captopril for heart failure in dogs. Dtsch. Tierärztliche Wochenschr. 1996, 103, 159-163.

152. Kitagawa, H.; Wakamiya, H.; Kitoh, K.; Kuwahara, Y.; Ohba, Y.; Isaji, M.; Iwasaki, T.; Nakano, M.; Sasaki, Y. Efficacy of monotherapy with benazepril, an angiotensin converting enzyme inhibitor, in dogs with naturally acquired chronic mitral insufficiency. J. Vet. Med. Sci. 1997, 59, 513-520. [CrossRef] [PubMed]

153. Biller, B.; Hörauf, A.; Kraft, W. Treatment of mitral valve insufficiency in dogs with the ACE inhibitor enalapril. A clinical progress study. Tierarztl Prax Ausg K Kleintiere Heimtiere 1998, 26, 21-30.

154. Uehara, Y.; Takahashi, M. Hemodynamic changes during administration of drugs for mitral regurgitation in dogs. J. Vet. Med. Sci. 1998, 60, 213-218. [CrossRef]

155. Ettinger, S.J.; Benitz, A.M.; Ericsson, G.F.; Cifelli, S.; Jernigan, A.D.; Longhofer, S.L.; Trimboli, W.; Hanson, P.D. Effects of enalapril maleate on survival of dogs with naturally acquired heart failure. The Long-Term Investigation of Veterinary Enalapril (LIVE) Study Group. J. Am. Vet. Med. Assoc. 1998, 213, 1573-1577. [PubMed]

156. The BENCH Study Group. The effect of benazepril on survival times and clinical signs of dogs with congestive heart failure: Results of a multicenter, prospective, randomized, double-blinded, placebo-controlled, long-term clinical trial. J. Vet. Cardiol. 1999, 1, 7-18. [CrossRef]

157. Keister, D.M.; Kittleson, M.D.; Bonagura, J.D.; Pipers, F.S.; Knauer, K.W. Milrinone: A Clinical Trial in 29 Dogs with Moderate to Severe Congestive Heart Failure. J. Vet. Intern. Med. 1990, 4, 79-86. [CrossRef]

158. Kittleson, M.D. The efficacy and safety of milrinone for treating heart failure in dogs. Vet. Clin. N. Am. Small Anim. Pract. 1991, 21, 905-918. [CrossRef]

159. Ynaraja, R.E.; Montoya, A.A. Propentophylline: Its use in dogs with congestive heart failure. Part I. Med. Vet. 1998, 15, 399-408.

160. Ynaraja, R.E.; Montoya, A.A. Propentophylline: Can be use as general treatment for ageing dogs. Med. Vet. 1998, 15, 462-480.

161. Freeman, L.M.; Rush, J.E.; Kehayias, J.J.; Ross, J.N., Jr.; Meydani, S.N.; Brown, D.J.; Dolnikowski, G.G.; Marmor, B.N.; White, M.E.; Dinarello, C.A.; et al. Nutritional Alterations and the Effect of Fish Oil Supplementation in Dogs with Heart Failure. J. Vet. Intern. Med. 1998, 12, 440-448. [CrossRef]

162. Bright, J.M.; Mears, E. Chronic Heart Disease and Its Management. Vet. Clin. N. Am. Small Anim. Pract. 1998, 27, 1305-1329. [CrossRef]

163. Sisson, D. Evidence for or Against the Efficacy of Afterload Reducers for Management of Heart Failure in Dogs. Vet. Clin. N. Am. Small Anim. Pract. 1991, 21, 945-955. [CrossRef]

164. Watson, A.D.; Church, D.B. Preferences of veterinarians for drugs to treat heart disease in dogs and cats. Aust. Vet. J. 1995, 72, 401-403. [CrossRef] [PubMed]

165. Chen, H.H.; Grantham, J.A.; Schirger, J.A.; Jougasaki, M.; Redfield, M.M.; Burnett, J.C., Jr. Subcutaneous Administration of Brain Natriuretic Peptide in Experimental Heart Failure. J. Am. Coll. Cardiol. 2000, 63, 1706-1712. [CrossRef]

166. Lainchbury, J.G.; Burnett, J.C., Jr.; Meyer, D.; Redfield, M.M. Effects of natriuretic peptides on load and myocardial function in normal and heart failure dogs. Am. J. Physiol.-Heart Circ. Physiol. 2000, 278, 33-40. [CrossRef]

167. Mishima, T.; Tanimura, M.; Suzuki, G.; Todor, A.; Sharov, V.G.; Goldstein, S.; Sabbah, H.N. Effects of Long-Term Therapy with Bosentan on the Progression of Left Ventricular Dysfunction and Remodeling in Dogs with Heart Failure. J. Am. Coll. Cardiol. 2000, 35, 222-229. [CrossRef]

168. Sabbah, H.N.; Sharov, V.G.; Gupta, R.C.; Todor, A.; Singh, V.; Goldstein, S. Chronic Therapy with Metoprolol Attenuates Cardiomyocyte Apoptosis in Dogs with Heart Failure. J. Am. Coll. Cardiol. 2000, 36, 1698-1705. [CrossRef]

169. Solter, P.; Sisson, D.; Thomas, W.; Goetze, L. Intrarenal Effects of Ecadotril during Acute Volume Expansion in Dogs with Congestive Heart Failure. J. Pharmacol. Exp. Ther. 2000, 293, 989-995.

170. Shen, Y.T.; Buie, P.S.; Lynch, J.J.; Krause, S.M.; Ma, X.L. Chronic therapy with an ET receptor antagonist in conscious dogs A/B during progression of congestive heart failure 21 Intracellular Ca regulation and nitric oxide mediated coronary relaxation. Cardiovasc. Res. 2000, 48, 332-345. [CrossRef]

171. Sabbah, H.N.; Stanley, W.C.; Sharov, V.G.; Mishima, T.; Tanimura, M.; Benedict, C.R.; Hegde, S.; Goldstein, S. Effects of Dopamine b-Hydroxylase Inhibition with Nepicastat on the Progression of Left Ventricular Dysfunction and Remodeling in Dogs With Chronic Heart Failure. Circulation 2000, 102, 1990-1995. [CrossRef]

172. Tanimura, M.; Mishima, T.; Steinberg, M.I.; Borzak, S.; Goldstein, S.; Sabbah, H.N. Hemodynamic effects of a novel sodium channel activator in dogs with chronic heart failure. Cardiovasc. Drugs Ther. 2000, 14, 77-82. [CrossRef]

173. Li, D.; Shinagawa, K.; Pang, L.; Leung, T.K.; Cardin, S.; Wang, Z.; Nattel, S. Effects of Angiotensin-Converting Enzyme Inhibition on the Development of the Atrial Fibrillation Substrate in Dogs With Ventricular Tachypacing-Induced Congestive Heart Failure. Circulation 2001, 104, 2608-2614. [CrossRef] [PubMed]

174. Oikawa, Y.; Maehara, K.; Saito, T.; Tamagawa, K.; Maruyama, Y. Attenuation of Angiotensin II-Mediated Coronary Vasoconstriction and Vasodilatory Action of Angiotensin-Converting Enzyme Inhibitor in Pacing-Induced Heart Failure in Dogs. J. Am. Coll. Cardiol. 2001, 38, 1188-1194. [CrossRef]

175. Sabbah, H.N.; Haddad, W.; Mika, Y.; Nass, O.; Aviv, R.; Sharov, V.G.; Maltsev, V.; Felzen, B.; Undrovinas, A.I.; Goldstein, S.; et al. Cardiac contractility modulation with the impulse dynamics signal: Studies in dogs with chronic heart failure. Heart Fail. Rev. 2001, 6, 45-53. [CrossRef] 
176. Nemoto, S.; Hamawaki, M.; De Freitas, G.; Carabello, B.A. Differential Effects of the Angiotensin-Converting Enzyme Inhibitor Lisinopril Versus the Beta- Adrenergic Receptor Blocker Atenolol on Hemodynamics and Left Ventricular Contractile Function in Experimental Mitral Regurgitation. J. Am. Coll. Cardiol. 2002, 40, 149-154. [CrossRef]

177. Mishima, T.; Tanimura, M.; Suzuki, G.; Todor, A.; Sharov, V.G.; Tanhehco, E.J.; Goldstein, S.; Sabbah, H.N. Effects of chronic neutral endopeptidase inhibition on the progression of left ventricular dysfunction and remodeling in dogs with moderate heart failure. Cardiovasc. Drugs Ther. 2002, 16, 209-214. [CrossRef] [PubMed]

178. Morita, H.; Suzuki, G.; Mishima, T.; Chaudhry, P.A.; Anagnostopoulos, P.V.; Tanhehco, E.J.; Sharov, V.G.; Goldstein, S.; Sabbah, H.N. Effects of long-term monotherapy with metoprolol CR/XL on the progression of left ventricular dysfunction and remodeling in dogs with chronic heart failure. Cardiovasc. Drugs Ther. 2002, 16, 443-449. [CrossRef]

179. Suzuki, G.; Morita, H.; Mishima, T.; Sharov, V.G.; Todor, A.; Tanhehco, E.J.; Rudolph, A.E.; McMahon, E.G.; Goldstein, S.; Sabbah, H.N. Effects of Long-Term Monotherapy With Eplerenone, a Novel Aldosterone Blocker, on Progression of Left Ventricular Dysfunction and Remodeling in Dogs With Heart Failure. Circulation 2002, 106, 2967-2972. [CrossRef]

180. Sabbah, H.N.; Chandler, M.P.; Mishima, T.; Suzuki, G.; Chaudhry, P.; Nass, O.; Biesiadecki, B.J.; Blackburn, B.; Wolff, A.; Stanley, W.C. Ranolazine, a Partial Fatty Acid Oxidation (pFOX) Inhibitor, Improves Left Ventricular Function in Dogs With Chronic Heart Failure. J. Card. Fail. 2002, 8, 416-422. [CrossRef]

181. Xu, X.; Zeng, G.; Yang, Y.; Liu, H.X. Recombinant human brain natriuretic peptide on the cardiac hemodynamics and renal function in dogs with heart failure. Yao Xиe Xue Bao 2002, 37, 758-762.

182. Chandler, M.P.; Stanley, W.C.; Morita, H.; Suzuki, G.; Roth, B.A.; Blackburn, B.; Wolff, A.; Sabbah, H.N. Short-Term Treatment with Ranolazine Improves Mechanical Efficiency in Dogs With Chronic Heart Failure. Circ. Res. 2002, 91, 278-280. [CrossRef] [PubMed]

183. Yamamoto, T.; Wada, A.; Ohnishi, M.; Tsutamoto, T.; Fujii, M.; Matsumoto, T.; Takayama, T.; Wang, X.; Kurokawa, K.; Kinoshita, M. Chronic administration of phosphodiesterase type 5 inhibitor suppresses renal production of endothelin- 1 in dogs with congestive heart failure. Clin. Sci. 2002, 103, 258-262. [CrossRef] [PubMed]

184. Koji, T.; Onishi, K.; Dohi, K.; Okamoto, R.; Tanabe, M.; Kitamura, T.; Ito, M.; Isaka, N.; Nobori, T.; Nakano, T. Addition of Angiotensin II Receptor Antagonist to an ACE Inhibitor in Heart Failure Improves Cardiovascular Function by a BradykininMediated Mechanism. J. Cardiovasc. Pharmacol. 2003, 41, 632-639. [CrossRef] [PubMed]

185. Tonduango, D.; Hittinger, L.; Ghaleh, B.; Le Corvoisier, P.; Sambin, L.; Champagne, S.; Badoual, T.; Vincent, F.; Berdeaux, A.; Crozatier, B.; et al. Chronic Infusion of Bradykinin Delays the Progression of Heart Failure and Preserves Vascular EndotheliumMediated Vasodilation in Conscious Dogs. Circulation 2004, 109, 114-119. [CrossRef]

186. Morita, H.; Suzuki, G.; Haddad, W.; Mika, Y.; Tanhehco, E.J.; Sharov, V.G.; Goldstein, S.; Ben-Haim, S.; Sabbah, H.N. Cardiac Contractility Modulation With Nonexcitatory Electric Signals Improves Left Ventricular Function in Dogs With Chronic Heart Failure. J. Card. Fail. 2003, 9, 69-75. [CrossRef]

187. Sun, W.; Liu, J. Effects of ginsenoside Rg2 on heart failure induced by pentobarbital sodium in dogs. Chin. Pharmacol. Bull. 2003, 19, 671-674.

188. Suzuki, G.; Mishima, T.; Tanhehco, E.J.; Sharov, V.G.; Todor, A.; Rostogi, S.; Gupta, R.C.; Chaudhry, P.A.; Anagnostopoulos, P.V.; Nass, O; et al. Effects of the AT1-receptor antagonist eprosartan on the progression of left ventricular dysfunction in dogs with heart failure. Br. J. Pharmacol. 2003, 138, 301-309. [CrossRef]

189. Cataliotti, A.; Boerrigter, G.; Costello-Boerrigter, L.C.; Schirger, J.A.; Tsuruda, T.; Heublein, D.M.; Chen, H.H.; Malatino, L.S.; Burnett, J.C., Jr. Brain Natriuretic Peptide Enhances Renal Actions of Furosemide and Suppresses Furosemide-Induced Aldosterone Activation in Experimental Heart Failure. Circulation 2004, 109, 1680-1685. [CrossRef]

190. Funabiki, K.; Onishi, K.; Dohi, K.; Koji, T.; Imanaka-Yoshida, K.; Ito, M.; Wada, H.; Isaka, N.; Nobori, T.; Nakano, T. Combined angiotensin receptor blocker and ACE inhibitor on myocardial fibrosis and left ventricular stiffness in dogs with heart failure. Am. J. Physiol.-Heart Circ. Physiol. 2004, 287, 2487-2492. [CrossRef] [PubMed]

191. Onishi, K.; Dohi, K.; Koji, T.; Funabiki, K.; Kitamura, T.; Imanaka-Yoshida, K.; Ito, M.; Nobori, T.; Nakano, T. Candesartan Prevents Myocardial Fibrosis during Progression of Congestive Heart Failure. J. Cardiovasc. Pharmacol. 2004, 43, 860-867. [CrossRef]

192. Okuda, S.; Yano, M.; Doi, M.; Oda, T.; Tokuhisa, T.; Kohno, M.; Kobayashi, S.; Yamamoto, T.; Ohkusa, T.; Matsuzaki, M. Valsartan Restores Sarcoplasmic Reticulum Function with No Appreciable Effect on Resting Cardiac Function in Pacing-Induced Heart Failure. Circulation 2004, 109, 911-919. [CrossRef] [PubMed]

193. Amado, L.C.; Saliaris, A.P.; Raju, S.V.; Lehrke, S.; St John, M.; Xie, J.; Stewart, G.; Fitton, T.; Minhas, K.M.; Brawn, J.; et al. Xanthine oxidase inhibition ameliorates cardiovascular dysfunction in dogs with pacing-induced heart failure. J. Mol. Cell. Cardiol. 2005, 39, 531-536. [CrossRef] [PubMed]

194. Nemoto, S.; Razeghi, P.; Ishiyama, M.; De Freitas, G.; Taegtmeyer, H.; Carabello, B.A. PPAR-y agonist rosiglitazone ameliorates ventricular dysfunction in experimental chronic mitral regurgitation. Am. J. Physiol.-Heart Circ. Physiol. 2005, 288, 77-82. [CrossRef]

195. Tachibana, H.; Cheng, H.; Ukai, T.; Igawa, A.; Zhang, Z.S.; Little, W.C.; Cheng, C.P. Levosimendan improves LV systolic and diastolic performance at rest and during exercise after heart failure. Am. J. Physiol.-Heart Circ. Physiol. 2005, 288, 914-922. [CrossRef] [PubMed]

196. Lin, Y.; Xu, C.; Deng, Y.L.; Chen, L.; Huang, H.; Du, J. Effects of tetramethylpyrazine on fibrosis of atrial tissue and atrial fibrillation in a canine model of congestive heart failure induced by ventricular tachypacing. Zhong Xi Yi Jie He Xue Bao 2006, 4, 35-38. [CrossRef] [PubMed] 
197. Morita, H.; Khanal, S.; Rastogi, S.; Suzuki, G.; Imai, M.; Todor, A.; Sharov, V.G.; Goldstein, S.; O’Neill, T.P.; Sabbah, H.N. Selective matrix metalloproteinase inhibition attenuates progression of left ventricular dysfunction and remodeling in dogs with chronic heart failure. Am. J. Physiol.-Heart Circ. Physiol. 2006, 290, 2522-2527. [CrossRef]

198. Papp, J.G.; Pollesello, P.; Varró, A.; Végh, A.; Udvary, E. The Effect of Levosimendan during Long-Term Amiodarone Treatment in Dogs. Basic Clin. Pharmacol. Toxicol. 2006, 99, 27-32. [CrossRef]

199. Shroff, S.C.; Ryu, K.; Martovitz, N.L.; Hoit, B.D.; Stambler, B.S. Selective aldosterone blockade suppresses atrial tachyarrhythmias in heart failure. J. Cardiovasc. Electrophysiol. 2006, 17, 534-541. [CrossRef]

200. Undrovinas, A.I.; Belardinelli, L.; Undrovinas, N.A.; Sabbah, H.N. Ranolazine improves abnormal repolarization and contraction in left ventricular myocytes of dogs with heart failure by inhibiting late sodium current. J. Cardiovasc. Electrophysiol. 2006, 17, 169-177. [CrossRef]

201. Cheng, Y.; George, I.; Yi, G.H.; Reiken, S.; Gu, A.; Tao, Y.K.; Muraskin, J.; Qin, S.; He, K.L.; Hay, I.; et al. Bradycardic therapy improves left ventricular function and remodeling in dogs with coronary embolization-induced chronic heart failure. J. Pharmacol. Exp. Ther. 2007, 321, 469-476. [CrossRef]

202. Imai, M.; Rastogi, S.; Sharma, N.; Chandler, M.P.; Sharov, V.G.; Blackburn, B.; Belardinelli, L.; Stanley, W.C.; Sabbah, H.N. CVT-4325 Inhibits Myocardial Fatty Acid Uptake and Improves Left Ventricular Systolic Function without Increasing Myocardial Oxygen Consumption in Dogs with Chronic Heart Failure. Cardiovasc. Drugs Ther. 2007, 21, 9-15. [CrossRef]

203. Rastogi, S.; Mishra, S.; Zacà, V.; Alesh, I.; Gupta, R.C.; Goldstein, S.; Sabbah, H.N. Effect of Long-term Monotherapy with the Aldosterone Receptor Blocker Eplerenone on Cytoskeletal Proteins and Matrix Metalloproteinases in Dogs with Heart Failure. Cardiovasc. Drugs Ther. 2007, 21, 415-422. [CrossRef] [PubMed]

204. Zacà, V.; Rastogi, S.; Imai, M.; Wang, M.; Sharov, V.G.; Jiang, A.; Goldstein, S.; Sabbah, H.N. Chronic Monotherapy With Rosuvastatin Prevents Progressive Left Ventricular Dysfunction and Remodeling in Dogs With Heart Failure. J. Am. Coll. Cardiol. 2007, 50, 551-557. [CrossRef] [PubMed]

205. Sabbah, H.N.; Imai, M.; Cowart, D.; Amato, A.; Carminati, P.; Gheorghiade, M. Hemodynamic Properties of a New-Generation Positive Luso-Inotropic Agent for the Acute Treatment of Advanced Heart Failure. Am. J. Cardiol. 2007, 99, 41-46. [CrossRef]

206. Shiroshita-Takeshita, A.; Brundel, B.; Burstein, B.; Leung, T.K.; Mitamura, H.; Ogawa, S.; Nattel, S. Effects of simvastatin on the development of the atrial fibrillation substrate in dogs with congestive heart failure. Cardiovasc. Res. 2007, 74, 75-84. [CrossRef] [PubMed]

207. Suzuki, G.; Khanal, S.; Rastogi, S.; Morita, H.; Mishima, T.; Anagnostopoulos, P.V.; Nass, O.; Sharov, V.G.; Tanhehco, E.J.; Goldstein, S.; et al. Long-term Pharmacological Activation of PPARg Does not Prevent Left Ventricular Remodeling in Dogs with Advanced Heart Failure. Cardiovasc. Drugs Ther. 2007, 21, 29-36. [CrossRef]

208. Imai, M.; Rastogi, S.; Gupta, R.C.; Mishra, S.; Sharov, V.G.; Stanley, W.C.; Mika, Y.; Rousso, B.; Burkhoff, D.; Ben-Haim, S.; et al. Therapy With Cardiac Contractility Modulation Electrical Signals Improves Left Ventricular Function and Remodeling in Dogs With Chronic Heart Failure. J. Am. Coll. Cardiol. 2007, 49, 2120-2128. [CrossRef]

209. Masutani, S.; Cheng, H.; Hyttilä-Hopponen, M.; Levijoki, J.; Heikkilä, A.; Vuorela, A.; Little, W.C.; Cheng, C.P. Orally available levosimendan dose-related positive inotropic and lusitropic effect in conscious chronically instrumented normal and heart failure dogs. J. Pharmacol. Exp. Ther. 2008, 325, 236-247. [CrossRef]

210. Rastogi, S.; Sharov, V.G.; Mishra, S.; Gupta, R.C.; Blackburn, B.; Belardinelli, L.; Stanley, W.C.; Sabbah, H.N. Ranolazine combined with enalapril or metoprolol prevents progressive LV dysfunction and remodeling in dogs with moderate heart failure. Am. J. Physiol.-Heart Circ. Physiol. 2008, 295, 2149-2155. [CrossRef]

211. Rastogi, S.; Imai, M.; Sharov, V.G.; Mishra, S.; Sabbah, H.N. Darbepoetin-alpha prevents progressive left ventricular dysfunction and remodeling in nonanemic dogs with heart failure. Am. J. Physiol.-Heart Circ. Physiol. 2008, 295, 2475-2482. [CrossRef]

212. Pat, B.; Killingsworth, C.; Denney, T.; Zheng, J.; Powell, P.; Tillson, M.; Dillon, A.R.; Dell'Italia, L.J. Dissociation between cardiomyocyte function and remodeling with beta-adrenergic receptor blockade in isolated canine mitral regurgitation. Am. J. Physiol.-Heart Circ. Physiol. 2008, 295, 2321-2327. [CrossRef]

213. Yang, S.; Han, W.; Zhou, H.Y.; Dong, G.; Wang, B.C.; Huo, H.; Wei, N.; Cao, Y.; Zhou, G.; Xiu, C.H.; et al. Effects of spironolactone on electrical and structural remodeling of atrium in congestive heart failure dogs. Chin. Med. J. 2008, 121, 38-42. [CrossRef] [PubMed]

214. Sasaki, H.; Asanuma, H.; Fujita, M.; Takahama, H.; Wakeno, M.; Ito, S.; Ogai, A.; Asakura, M.; Kim, J.; Minamino, T.; et al. Metformin Prevents Progression of Heart Failure in Dogs Role of AMP-Activated Protein Kinase. Circulation 2009, 119, $2568-2577$. [CrossRef] [PubMed]

215. Zacà, V.; Rastogi, S.; Mishra, S.; Wang, M.; Sharov, V.G.; Gupta, R.C.; Goldstein, S.; Sabbah, H.N. Atenolol Is Inferior to Metoprolol in Improving Left Ventricular Function and Preventing Ventricular Remodeling in Dogs with Heart Failure. Cardiology 2009, 112, 294-302.

216. Sawangkoon, S.; Miyamoto, M.; Nakayama, T.; Hamlin, R.L. Acute cardiovascular effects and pharmacokinetics of carvedilol in healthy dogs. Am. J. Vet. Res. 2000, 61, 57-60. [CrossRef]

217. Olivier, N.B.; Kutas, S.M.; Beals, S.; Hanson, B.; Windram, S. Short-term effects of ecadotril in dogs with induced congestive heart failure. Am. J. Vet. Res. 2000, 61, 333-338. [CrossRef] 
218. Asano, K.; Masuda, K.; Okumura, M.; Kadosawa, T.; Fujinaga, T. Association between exogenous atrial natriuretic peptide and hemodynamics in dogs with congestive heart failure produced by experimental mitral regurgitation. J. Vet. Med. Sci. 2001, 63, 243-250. [CrossRef] [PubMed]

219. Uechi, M.; Sasaki, T.; Ueno, K.; Yamamoto, T.; Ishikawa, Y. Cardiovascular and renal effects of carvedilol in dogs with heart failure. J. Vet. Med. Sci. 2002, 64, 469-475. [CrossRef] [PubMed]

220. Uechi, M.; Matsuoka, M.; Kuwajima, E.; Kaneko, T.; Yamashita, K.; Fukushima, U.; Ishikawa, Y. The effects of the loop diuretics furosemide and torasemide on diuresis in dogs and cats. J. Vet. Med. Sci. 2003, 65, 1057-1061. [CrossRef]

221. Arsenault, W.G.; Boothe, D.M.; Gordon, S.G.; Miller, M.W.; Chalkley, J.R.; Petrikovics, I. Pharmacokinetics of carvedilol after intravenous and oral administration in conscious healthy dogs. Am. J. Vet. Res. 2005, 66, 2172-2176. [CrossRef]

222. Abbott, J.A.; Broadstone, R.V.; Ward, D.L.; Pyle, R.L. Hemodynamic effects of orally administered carvedilol in healthy conscious dogs. Am. J. Vet. Res. 2005, 66, 637-641. [CrossRef] [PubMed]

223. Gordon, S.G.; Arsenault, W.G.; Longnecker, M.; Boothe, D.M.; Miller, M.W.; Chalkley, J. Pharmacodynamics of Carvedilol in Conscious, Healthy Dogs. J. Vet. Intern. Med. 2006, 20, 297-304. [CrossRef]

224. Nakayama, T.; Nishijima, Y.; Miyamoto, M.; Hamlin, R.L. Effects of 4 Classes of Cardiovascular Drugs on Ventricular Function in Dogs with Mitral Regurgitation. J. Vet. Intern. Med. 2007, 21, 445-450. [CrossRef]

225. Atkins, C.E.; Rausch, W.P.; Gardner, S.Y.; Defrancesco, T.C.; Keene, B.W.; Levine, J.F. The effect of amlodipine and the combination of amlodipine and enalapril on the renin-angiotensin-aldosterone system in the dog. J. Vet. Pharmacol. Ther. 2007, 30, 394-400. [CrossRef] [PubMed]

226. Kanno, N.; Kuse, H.; Kawasaki, M.; Hara, A.; Kano, R.; Sasaki, Y. Effects of pimobendan for mitral valve regurgitation in dogs. J. Vet. Med. Sci. 2007, 69, 373-377. [CrossRef] [PubMed]

227. Chetboul, V.; Lefebvre, H.; Sampedrano, C.C.; Gouni, V.; Saponaro, V.; Serres, F.; Concodert, D.; Nicolle, A.P.; Pouchelon, J. Comparative Adverse Cardiac Effects of Pimobendan and Benazepril Monotherapy in Dogs with Mild Degenerative Mitral Valve Disease: A Prospective, Controlled, Blinded, and Randomized Study. J. Vet. Intern. Med. 2007, 21, 742-753. [CrossRef] [PubMed]

228. Hori, Y.; Takusagawa, F.; Ikadai, H.; Uechi, M.; Hoshi, F.; Higuchi, S. Effects of oral administration of furosemide and torsemide in healthy dogs. Am. J. Vet. Res. 2007, 68, 1058-1063. [CrossRef] [PubMed]

229. Beddies, G.; Fox, P.R.; Papich, M.D.; Kanikanti, V.R.; Krebber, R.; Keene, B.W. Comparison of the pharmacokinetic properties of bisoprolol and carvedilol in healthy dogs. Am. J. Vet. Res. 2008, 69, 1659-1663. [CrossRef]

230. Hori, Y.; Katou, A.; Tsubaki, M.; Kanai, K.; Nakao, R.; Hoshi, F.; Itoh, N.; Higuchi, S. Assessment of diuretic effects and changes in plasma aldosterone concentration following oral administration of a single dose of furosemide or azosemide in healthy dogs. Am. J. Vet. Res. 2008, 69, 1664-1669. [CrossRef]

231. Sayer, M.B.; Atkins, C.E.; Fujii, Y.; Adams, A.K.; Defrancesco, T.C.; Keene, B.W. Acute effect of pimobendan and furosemide on the circulating renin-angiotensin-aldosterone system in healthy dogs. J. Vet. Intern. Med. 2009, 23, 1003-1006. [CrossRef]

232. Atkins, C.E.; Brown, W.A.; Coats, J.R.; Crawford, M.A.; Defrancesco, T.C.; Edwards, J.; Fox, P.R.; Keene, B.W.; Lehmkhul, L.; Luethy, M.; et al. Effects of long-term administration of enalapril on clinical indicators of renal function in dogs with compensated mitral regurgitation. J. Am. Vet. Med. Assoc. 2002, 221, 654-658. [CrossRef] [PubMed]

233. The BENCH Study Group. Long-term tolerability of benazepril in dogs with congestive heart failure. J. Vet. Cardiol. 2004, 6, 7-13. [CrossRef]

234. Amberger, C.; Chetboul, V.; Bomassi, E.; Rougier, S.; Woehrlé, F.; Thoulon, F.; FIRST Group. Comparison of the effects of imidapril and enalapril in a prospective, multicentric randomized trial in dogs with naturally acquired heart failure. J. Vet. Cardiol. 2004, 6, 9-16. [CrossRef]

235. Besche, B.; Chetboul, V.; Lachaud Lefay, M.P.; Grandemange, E. Clinical evaluation of imidapril in congestive heart failure in dogs: Results of the EFFIC study. J. Small Anim. Pract. 2007, 48, 265-270. [CrossRef] [PubMed]

236. Rush, J.E.; Freeman, L.M.; Hiler, C.; Brown, D.J. Use of metoprolol in dogs with acquired cardiac disease. J. Vet. Cardiol. 2002, 4, 23-28. [CrossRef]

237. Abbott, J.A. Beta-blockade in the management of systolic dysfunction. Vet. Clin. N. Am. Small Anim. Pract. 2004, 34, 1157-1170. [CrossRef] [PubMed]

238. Marcondes-Santos, M.; Tarasoutchi, F.; Mansur, A.P.; Strunz, C.M.C. Effects of Carvedilol Treatment in Dogs with Chronic Mitral Valvular Disease. J. Vet. Intern. Med. 2007, 21, 996-1001. [CrossRef] [PubMed]

239. Bach, J.F.; Rozanski, E.A.; MacGregor, J.; Betkowski, J.M.; Rush, J.E. Retrospective Evaluation of Sildenafil Citrate as a Therapy for Pulmonary Hypertension in Dogs. J. Vet. Intern. Med. 2006, 20, 1132-1135. [CrossRef]

240. Kellum, H.B.; Stepien, R.L. Sildenafil Citrate Therapy in 22 Dogs with Pulmonary Hypertension. J. Vet. Intern. Med. 2007, 21, 1258-1264. [CrossRef] [PubMed]

241. Saunders, A.B.; Miller, M.W.; Gordon, S.G.; Van De Wiele, C.M. Oral Amiodarone Therapy in Dogs with Atrial Fibrillation. J. Vet. Intern. Med. 2006, 20, 921-926. [CrossRef] [PubMed]

242. Caro-Vadillo, A.; Ynaraja-Ramirez, E.; Montoya-Alonso, J.A. Effect of torsemide on serum and urine electrolyte levels in dogs with congestive heart failure. Vet. Rec. 2007, 160, 847-848. [CrossRef]

243. Adin, D.B.; Kittleson, M.D.; Hornof, W.J.; Kass, P.H. Efficacy of a Single Oral Dose of Isosorbide 5 Mononitrate in Normal Dogs and in Dogs with Congestive Heart Failure. J. Vet. Intern. Med. 2001, 15, 105-111. [CrossRef] [PubMed] 
244. Thomason, J.D.; Fallaw, T.L.; Carmichael, K.P.; Radlinsky, M.A.; Calvert, C.A. Gingival Hyperplasia Associated with the Administration of Amlodipine to Dogs with Degenerative Valvular Disease (2004-2008). J. Vet. Intern. Med. 2009, $23,39-42$. [CrossRef] [PubMed]

245. Tissier, R.; Chetboul, V.; Moraillon, R.; Nicolle, A.; Carlos, C.; Enriquez, B.; Pouchelon, J.L. Increased Mitral Valve Regurgitation and Myocardial Hypertrophy in Two Dogs With Long-Term Pimobendan Therapy. Cardiovasc. Toxicol. 2005, 5, 43-51. [CrossRef]

246. Smith, P.J.; French, A.T.; Van Israël, N.; Smith, S.G.W.; Swift, S.T.; Lee, A.J.; Corcoran, B.M.; Dukes-McEwan, J. Efficacy and safety of pimobendan in canine heart failure caused by myxomatous mitral valve disease. J. Small Anim. Pract. 2005, 46, 121-130. [CrossRef]

247. Gordon, S.G.; Miller, M.W.; Saunders, A.B. Pimobendan in heart failure therapy-A silver bullet? J. Am. Anim. Hosp. Assoc. 2006, 42, 90-93. [CrossRef]

248. Caro, A.; Ynaraja, E.; Montoya, J.A. Effects of Short-term Treatment with Pimobendan in Dogs with Myxomatous Valve Disease. J. Appl. Anim. Res. 2009, 35, 113-117. [CrossRef]

249. Atkinson, K.J.; Fine, D.M.; Thombs, L.A.; Gorelick, J.J.; Durham, H.E. Evaluation of Pimobendan and N-Terminal Probrain Natriuretic Peptide in the Treatment of Pulmonary Hypertension Secondary to Degenerative Mitral Valve Disease in Dogs. J. Vet. Intern. Med. 2009, 23, 1190-1196. [CrossRef]

250. Häggström, J.; Boswood, A.; O’Grady, M.; Jöns, O.; Smith, S.; Swift, S.; Borgarelli, M.; Gavaghan, B.; Kresken, J.G.; Patteson, M.; et al. Effect of Pimobendan or Benazepril Hydrochloride on Survival Times in Dogs with Congestive Heart Failure Caused by Naturally Occurring Myxomatous Mitral Valve Disease: The QUEST Study. J. Vet. Intern. Med. 2008, 22, 1124-1135. [CrossRef]

251. Lombard, C.W.; Jöns, O.; Bussadori, C.M. Clinical efficacy of pimobendan versus benazepril for the treatment of acquired atrioventricular valvular disease in dogs. J. Am. Anim. Hosp. Assoc. 2006, 42, 249-261. [CrossRef]

252. Gelzer, A.R.M.; Kraus, M.S.; Rishniw, M.; Moïse, N.S.; Pariaut, R.; Jesty, S.A.; Hemsley, S.A. Combination Therapy with Digoxin and Diltiazem Controls Ventricular Rate in Chronic Atrial Fibrillation in Dogs Better than Digoxin or Diltiazem Monotherapy: A Randomized Crossover Study in 18 Dogs. J. Vet. Intern. Med. 2009, 23, 499-508. [CrossRef]

253. Chandler, M.L. Pet food safety: Sodium in pet foods. Top. Companion. Anim. Med. 2008, 23, 148-153. [CrossRef] [PubMed]

254. Rush, J.E.; Freeman, L.M.; Brown, D.J.; Brewer, B.P.; Ross, J.N.; Markwell, P.J. Clinical, Echocardiographic, and Neurohormonal Effects of a Sodium-Restricted Diet in Dogs with Heart Failure. J. Vet. Intern. Med. 2000, 14, 513-520. [CrossRef] [PubMed]

255. Martinez-Alcaine, M.A.; Ynaraja, E.; Corbera, J.A.; Montoya, J.A. Effect of short-term treatment with bumetanide, quinapril and low-sodium diet on dogs with moderate congestive heart failure. Aust. Vet. J. 2001, 79, 102-105. [CrossRef]

256. Freeman, L.M.; Rush, J.E.; Cahalane, A.K.; Markwell, P.J. Dietary Patterns of Dogs with Cardiac Disease. J. Nutr. 2002, 132, 1632-1633. [CrossRef]

257. Caro-Vadillo, A.; Ynaraja-Ramirez, E.; Montoya-Alonso, J.A. Effect of Short-term Treatment with Perindopril, Torsemide and Restricted sodium Diet in Dogs with Atrioventricular Valvular Insufficiency. J. Appl. Anim. Res. 2006, 29, 105-108. [CrossRef]

258. Martin, M.W.S. Treatment of congestive heart failure-A neuroendocrine disorder. J. Small Anim. Pract. 2003, 44, 154-160. [CrossRef]

259. Häggström, J.; Duelund Pedersen, H.; Kvart, C. New insights into degenerative mitral valve disease in dogs. Vet. Clin. N. Am. Small Anim. Pract. 2004, 34, 1209-1226. [CrossRef] [PubMed]

260. Smith, P. Management of chronic degenerative mitral valve disease in dogs. Practice 2006, 28, 376-383. [CrossRef]

261. Lefebvre, H.P.; Brown, S.A.; Chetboul, V.; King, J.N.; Puchelon, J.L.; Toutain, P.L. Angiotensin-converting enzyme inhibitors in veterinary medicine. Curr. Pharm. Des. 2007, 13, 1347-1361. [CrossRef]

262. Häggström, J.; Höglund, K.; Borgarelli, M. An update on treatment and prognostic indicators in canine myxomatous mitral valve disease. J. Small Anim. Pract. 2009, 50, 25-33. [CrossRef]

263. Stepien, R.L. Pulmonary arterial hypertension secondary to chronic left-sided cardiac dysfunction in dogs. J. Small Anim. Pract. 2009, 50, 34-43. [CrossRef]

264. Oyama, M.A. Neurohormonal activation in canine degenerative mitral valve disease: Implications on pathophysiology and treatment. J. Small Anim. Pract. 2009, 50, 3-11. [CrossRef]

265. Takahama, H.; Asanuma, H.; Sanada, S.; Fujita, M.; Sasaki, H.; Wakeno, M.; Kim, J.; Asakura, M.; Takashima, S.; Minamino, T.; et al. A histamine $\mathrm{H} 2$ receptor blocker ameliorates development of heart failure in dogs independently of b-adrenergic receptor blockade. Basic Res. Cardiol. 2010, 105, 787-794. [CrossRef] [PubMed]

266. Onogawa, T.; Sakamoto, Y.; Nakamura, S.; Nakayama, S.; Fujiki, H.; Yamamura, Y. Effects of Tolvaptan on Systemic and Renal Hemodynamic Function in Dogs with Congestive Heart Failure. Cardiovasc. Drugs Ther. 2011, 25, 67-76. [CrossRef]

267. Sabbah, H.N.; Wang, M. Long-term therapy with a partial adenosine A1-Receptor agonist improves left ventricular systolic function and prevents progressive ventricular remodeling in dogs with chronic heart failure. Circulation 2011, $124,21$.

268. Boerrigter, G.; Soergel, D.G.; Violin, J.D.; Lark, M.W.; Burnett, J.C. TRV120027, a Novel $\beta$-Arrestin Biased Ligand at the Angiotensin II Type I Receptor, Unloads the Heart and Maintains Renal Function When Added to Furosemide in Experimental Heart Failure. Circ. Heart Fail. 2012, 5, 627-634. [CrossRef] [PubMed]

269. Speranza, L.; Franceschelli, S.; Riccioni, G. The Biological Effects of Ivabradine in Cardiovascular Disease. Molecules 2012, 17, 4924-4935. [CrossRef] [PubMed] 
270. Sakabe, M.; Fujiki, A.; Sakamoto, T.; Nakatani, Y.; Mizumaki, K.; Inoue, H. Xanthine Oxidase Inhibition Prevents Atrial Fibrillation in a Canine Model of Atrial Pacing-Induced left Ventricular Dysfunction. J. Cardiovasc. Electrophysiol. 2012, 23, 1130-1135. [CrossRef] [PubMed]

271. Zhou, S.; Fang, C.; Zheng, S.; Zhang, Y.; Lei, J.; Wang, J. Effect of amiodarone on dispersion of ventricular repolarization in a canine congestive heart failure model. Clin. Exp. Pharmacol. Physiol. 2012, 39, 241-246. [CrossRef] [PubMed]

272. Chello, M.; Spadaccio, C. Pleiotropic effects of long-term monotherapy with rosuvastatin in dogs with moderate heart failure. Cardiology 2013, 124, 36-37. [CrossRef]

273. Esposito, C.T.; Varahan, S.; Jeyaraj, D.; Lu, Y.; Stambler, B.S. Spironolactone improves the arrhythmogenic substrate in heart failure by preventing ventricular electrical activation delays associated with myocardial interstitial fibrosis and inflammation. $J$. Cardiovasc. Electrophysiol. 2013, 24, 806-812. [CrossRef]

274. Nakatani, Y.; Nishida, K.; Sakabe, M.; Kataoka, N.; Sakamoto, T.; Yamaguchi, Y.; Iwamoto, J.; Mizumaki, K.; Fujiki, A.; Inoue, H. Tranilast Prevents Atrial Remodeling and Development of Atrial Fibrillation in a Canine Model of Atrial Tachycardia and Left Ventricular Dysfunction. J. Am. Coll. Cardiol. 2013, 61, 582-588. [CrossRef]

275. Sabbah, H.N.; Gupta, R.C.; Kohli, S.; Wang, M.; Rastogi, S.; Zhang, K.; Zimmermann, K.; Diedrichs, N.; Albrecht-Küpper, B.E. Chronic Therapy with a Partial Adenosine A1 Receptor Agonist, Improves Left Ventricular Function and Remodeling in Dogs with Advanced Heart Failure. Circ. Heart Fail. 2013, 6, 563-571. [CrossRef]

276. Wang, M.; Gupta, R.C.; Rastogi, S.; Johli, S.; Sabbah, M.S.; Zhang, K.; Mohyi, P.; Hogie, M.; Fischer, Y.; Sabbah, H.N. Effects of acute intravenous infusion of apelin on left ventricular function in dogs with advanced heart failure. J. Card. Fail. 2013, 19, 509-516. [CrossRef] [PubMed]

277. Hamabe, L.; Kawamura, K.; Kim, S.; Yoshiyuki, R.; Fukuyama, T.; Shimizu, M.; Fukushima, R.; Tanaka, R. Comparative Evaluation of Calcium-Sensitizing Agents, Pimobendan and SCH00013, on the Myocardial Function of Canine Pacing-Induced Model of Heart Failure. J. Pharmacol. Sci. 2014, 124, 386-393. [CrossRef] [PubMed]

278. Li, Y.; Ji, Y.; Zhou, X.; Jiang, T.; Hong, Y.; Li, J.; Zing, Q.; Ziong, J.; Yusufuaji, Y.; Tang, B. Effects of Ivabradine on Cardiac Electrophysiology in Dogs with Age-Related Atrial Fibrillation. Med. Sci. Monit. 2015, 21, 1414-1420. [CrossRef] [PubMed]

279. Mochel, J.P.; Danhof, M. Chronobiology and Pharmacologic Modulation of the Renin-Angiotensin-Aldosterone System in Dogs: What Have We Learned? Rev. Physiol. Biochem. Pharmacol. 2015, 169, 43-69. [PubMed]

280. Sabbah, H.N.; Gupta, R.C. Long-term therapy with Bendavia (MTP-131), a novel mitochondria-targeting peptide, normalizes Complex-I Activity and reduces the NADH/NAD ratio in left ventricular myocardium of dogs with advanced heart failure. Mitochondrion 2015, 24, 21-22. [CrossRef]

281. Trappanese, D.M.; Liu, Y.; McCormick, R.C.; Cannavo, A.; Nanayakkara, G.; Baskharoun, M.M.; Jarrett, H.; Woitek, F.J.; Tillson, D.M.; Dillon, A.R.; et al. Chronic $\beta 1$-adrenergic blockade enhances myocardial $\beta 3$-adrenergic coupling with nitric oxide-cGMP signaling in a canine model of chronic volume overload: New insight into mechanisms of cardiac benefit with selective $\beta 1$-blocker therapy. Basic Res. Cardiol. 2015, 110, 456. [CrossRef]

282. Gupta, R.C.; Singh-Gupta, V.; Zhang, K.; Xu, J.; Sabbah, H.N. Elamipretide (Bendavia ${ }^{\mathrm{TM}}$ ) restores 4-hydroxy-2-nonenal protein adducts and aldehyde dehydrogenase-2 activity and mRNA expression in left ventricular myocardium of dogs with advanced heart failure. Circulation 2016, 134, A12949.

283. Gupta, R.C.; Singh-Gupta, V.; Sabbah, H.N. Long-term therapy with elamipretide normalizes protein levels of the signal transducer and activator of transcription 3 (STAT3) in mitochondria of left ventricular myocardium of dogs with chronic heart failure. Circulation 2016, 134, A12984.

284. Panthee, N.; Okada, J.; Washio, T.; Mochizuki, Y.; Suzuki, R.; Koyama, H.; Ono, M.; Hisada, T.; Sugiura, S. Tailor-made heart simulation predicts the effect of cardiac resynchronization therapy in a canine model of heart failure. Med. Image Anal. 2016, 31, 46-62. [CrossRef] [PubMed]

285. Sabbah, H.N.; Gupta, R.C.; Kohli, S.; Wang, M.; Hachem, S.; Zhang, K. Chronic Therapy with Elamipretide (MTP-131), a Novel Mitochondria-Targeting Peptide, Improves Left Ventricular and Mitochondrial Function in Dogs with Advanced Heart Failure. Circ. Heart Fail. 2016, 9, e002206. [CrossRef]

286. Sabbah, H.N.; Gupta, R.C. Long-term therapy with elamipretide normalizes ATP synthase activity in left ventricular myocardium of dogs with advanced heart failure. J. Card. Fail. 2016, 22, 23. [CrossRef]

287. Ames, M.K.; Atkins, C.E.; Lanyis, A.C.; zum Brunnen, J. Evaluation of subacute change in RAAS activity (as indicated by urinary aldosterone:creatinine, after pharmacologic provocation) and the response to ACE inhibition. J. Renin-Angiotensin-Aldosterone Syst. 2016, 17, 1470320316633897. [CrossRef]

288. Gupta, R.C.; Singh-Gupta, V.; Sabbah, H.N. Long-term therapy with elamipretide normalizes activation of the mitochondrial signal transducer and activator of transcription 3 (mstat3) in of left ventricular myocardium of dogs with chronic heart failure. $J$. Am. Coll. Cardiol. 2017, 69, 923. [CrossRef]

289. Sabbah, H.N.; Gupta, R.C. Long-term therapy with elamipretide reverses abnormalities of cardiolipin synthesis and remodeling in left ventricular myocardium of dogs with chronic heart failure. J. Card. Fail. 2017, 23, 25-26. [CrossRef]

290. Gupta, R.C.; Singh-Gupta, V.; Castle, K.; Sabbah, H.N. Long-term therapy with elamipretide normalizes sirtuin-3 protein levels in isolated mitochondria of left ventricular myocardium of dogs with chronic heart failure. J. Am. Coll. Cardiol. 2018, 71, 11. [CrossRef] 
291. Gupta, R.C.; Singh-Gupta, V.; Zhang, K.; Xu, J.; Sabbah, H.N. Elamipretide restores protein and mRNA expression levels of S100A1 in left ventricular myocardium of dogs with chronic heart failure. Eur. J. Heart Fail. 2018, 20, 150.

292. Sabbah, H.N.; Gupta, R.C.; Singh-Gupta, V.; Zhang, K.; Lanfear, D.E. Abnormalities of Mitochondrial Dynamics in the Failing Heart: Normalization Following Long-Term Therapy with Elamipretide. Cardiovasc. Drugs Ther. 2018, 32, 319-328. [CrossRef]

293. Gao, B.; Qu, Y.; Sutherland, W.; Chui, R.W.; Hoagland, K.; Vargas, H.M. Decreased contractility and altered responses to inotropic agents in myocytes from tachypacing-induced heart failure canines. J. Pharmacol. Toxicol. Methods 2018, 93, 98-107. [CrossRef] [PubMed]

294. Zhang, X.; Zhang, Z.; Li, T.; Cheng, H.-J.; Deal, D.D.; Jordan, J.E.; Adams, J.; Cheng, C.P. Apd418, a selective beta-adrenergic receptor antagonist enhances cardiac positive inotropic and lusitropic responses to dobutamine in conscious, chronicallyinstrumented dogs with pacing-induced heart failure: Assessment by pressure-volume analysis. Circulation 2018, 138 , A10553.

295. Tsujino, Y.; Sakamoto, T.; Kinoshita, K.; Nakatani, Y.; Yamaguchi, Y.; Kataoka, N.; Nishida, K.; Kinugawa, K. Edoxaban suppresses the progression of atrial fibrosis and atrial fibrillation in a canine congestive heart failure model. Heart Vessels 2019, 34, 1381-1388. [CrossRef] [PubMed]

296. Sabbah, H.N.; Gupta, R.C.; Singh-Gupta, V.; Zhang, K. Effects of elamipretide on skeletal muscle in dogs with experimentally induced heart failure. ESC Heart Fail. 2019, 6, 328-335. [CrossRef]

297. Mondritzki, T.; Mai, T.; Vogel, J.; Pook, E.; Wasnaire, P.; Schmeck, C.; Hüser, J.; Dinh, W.; Truebel, H.; Kolkhof, P. Cardiac output improvement by pecavaptan: A novel dual-acting vasopressin V1a/V2 receptor antagonist in experimental heart failure. Eur. J. Heart Fail. 2021, 23, 743-750. [CrossRef]

298. Sabbah, H.N.; Zhang, K.; Gupta, R.C.; Martin, E. Effects of Intravenous Infusion of Vepoloxamer on Left Ventricular Function in Dogs with Advanced Heart Failure. Cardiovasc. Drugs Ther. 2020, 34, 153-164. [CrossRef]

299. Guyonnet, J.; Elliott, J.; Kaltsatos, V. A preclinical pharmacokinetic and pharmacodynamic approach to determine a dose of spironolactone for treatment of congestive heart failure in dog. J. Vet. Pharmacol. Ther. 2010, 33, 260-267. [CrossRef]

300. Ishikawa, T.; Tanaka, R.; Suzuki, S.; Miyaishi, Y.; Akagi, H.; Iino, Y.; Fukushima, R.; Yamane, Y. The Effect of AngiotensinConverting Enzyme Inhibitors of Left Atrial Pressure in Dogs with Mitral Valve Regurgitation. J. Vet. Intern. Med. 2010, 24, 342-347. [CrossRef]

301. Lantis, A.C.; Atkins, C.E.; Defrancesco, T.C.; Keene, B.W.; Werre, S.R. Effects of furosemide and the combination of furosemide and the labeled dosage of pimobendan on the circulating renin-angiotensin-aldosterone system in clinically normal dogs. Am. J. Vet. Res. 2011, 72, 1646-1651. [CrossRef] [PubMed]

302. Suzuki, S.; Ishikawa, T.; Hamabe, L.; Aytemiz, D.; Huai-Che, H.; Fukushima, R.; Machida, N.; Tanaka, R. The Effect of Furosemide on Left Atrial Pressure in Dogs with Mitral Valve Regurgitation. J. Vet. Intern. Med. 2011, 25, 244-250. [CrossRef] [PubMed]

303. Suzuki, S.; Fukushima, R.; Ishikawa, T.; Hamabe, L.; Aytemiz, D.; Huahi-Che, H.; Nakao, S.; Machida, N.; Tanaka, R. The Effect of Pimobendan on Left Atrial Pressure in Dogs with Mitral Valve Regurgitation. J. Vet. Intern. Med. 2011, 25, 1328-1333. [CrossRef]

304. Suzuki, S.; Fukushima, R.; Ishikawa, T.; Yamamoto, Y.; Hamabe, L.; Kim, S.; Yoshiyuki, R.; Machida, N.; Tanaka, R. Comparative effects of amlodipine and benazepril on Left Atrial Pressure in Dogs with experimentally-induced Mitral Valve Regurgitation. BMC Vet. Res. 2012, 8, 166. [CrossRef] [PubMed]

305. Mochel, J.P.; Peyrou, M.; Fink, M.; Strehlau, G.; Mohamed, R.; Giraudel, J.M.; Ploeger, B.; Danhof, M. Capturing the dynamics of systemic Renin-Angiotensin-Aldosterone System (RAAS) peptides heightens the understanding of the effect of benazepril in dogs. J. Vet. Pharmacol. Ther. 2013, 36, 174-180. [CrossRef] [PubMed]

306. Ames, M.K.; Atkins, C.E.; Lantis, A.C.; Were, S.R. Effect of furosemide and high-dosage pimobendan administration on the renin-angiotensin-aldosterone system in dogs. Am. J. Vet. Res. 2013, 74, 1084-1090. [CrossRef] [PubMed]

307. Suzuki, S.; Fukushima, R.; Yamamoto, Y.; Ishikawa, T.; Hamabe, L.; Kim, S.; Yoshiyuki, R.; Fukuyama, T.; Machida, N.; Tanaka, R. Comparative Effect of Carperitide and Furosemide on Left Atrial Pressure in Dogs with Experimentally Induced Mitral Valve Regurgitation. J. Vet. Intern. Med. 2013, 27, 1097-1104. [CrossRef]

308. Lantis, A.C.; Ames, M.K.; Atkins, C.E.; Defrancesco, T.C.; Keene, B.W.; Werre, S.R. Aldosterone breakthrough with benazepril in furosemide-activated renin-angiotensin-aldosterone system in normal dogs. J. Vet. Pharmacol. Ther. 2015, 38, 65-73. [CrossRef]

309. Mochel, J.P.; Fink, M.; Peyrou, M.; Soubret, A.; Giraudel, J.M.; Danhof, M. Pharmacokinetic/Pharmacodynamic Modeling of Renin-Angiotensin Aldosterone Biomarkers Following Angiotensin-Converting Enzyme (ACE) Inhibition Therapy with Benazepril in Dogs. Pharm. Res. 2015, 32, 1931-1946. [CrossRef]

310. Lantis, A.C.; Ames, M.K.; Werre, S.; Atkins, C.E. The effect of enalapril on furosemide-activated renin-angiotensin- aldosterone system in healthy dogs. J. Vet. Pharmacol. Ther. 2015, 38, 513-517. [CrossRef]

311. Ames, M.K.; Atkins, C.E.; Lee, S.; Lantis, A.C.; zum Brunnen, J.R. Effects of high doses of enalapril and benazepril on the pharmacologically activated renin-angiotensin-aldosterone system in clinically normal dogs. Am. J. Vet. Res. 2015, 76, 1041-1050. [CrossRef] [PubMed]

312. Harada, K.; Ukai, Y.; Kanakubo, K.; Yamano, S.; Lee, J.; Kurosawa, T.A.; Uechi, M. Comparison of the diuretic effect of furosemide by different methods of administration in healthy dogs. J. Vet. Emerg. Crit. Care 2015, 25, 364-371. [CrossRef]

313. Yata, M.; McLachlan, A.J.; Foster, D.J.R.; Page, S.W.; Beijerink, N.J. Pharmacokinetics and cardiovascular effects following a single oral administration of a nonaqueous pimobendan solution in healthy dogs. J. Vet. Pharmacol. Ther. 2016, 39, 45-53. [CrossRef] [PubMed] 
314. Bell, E.T.; Devi, J.L.; Chiu, S.; Zahra, P.; Whittem, T. The pharmacokinetics of pimobendan enantiomers after oral and intravenous administration of racemate pimobendan formulations in healthy dogs. J. Vet. Pharmacol. Ther. 2016, 39, 54-61. [CrossRef]

315. Bieth, B.; Bornkamp, B.; Toutain, C.; Garcia, R.; Mochel, J.P. Multiple comparison procedure and modeling: A versatile tool for evaluating dose-response relationships in veterinary pharmacology-A case study with furosemide. J. Vet. Pharmacol. Ther. 2016, 39, 539-546. [CrossRef] [PubMed]

316. Paulin, A.; Schneider, M.; Dron, F.; Woehrlé, F. A pharmacokinetic/pharmacodynamic model capturing the time course of torasemide-induced diuresis in the dog. J. Vet. Pharmacol. Ther. 2016, 39, 547-559. [CrossRef]

317. Qian, M.; Chen, T.; Zhou, D.; Chang, Z.; Zhang, Q.; Tang, S.; Xiao, X. Development of a new benazepril hydrochloride chewable tablet and evaluation of its bioequivalence for treatment of heart failure in dogs. J. Vet. Pharmacol. Ther. 2016, 39, 98-101. [CrossRef]

318. Sakatani, A.; Miyagawa, Y.; Takemura, N. Evaluation of the effect of an angiotensin-converting enzyme inhibitor, alacepril, on drug-induced renineangiotensinealdosterone system activation in normal dogs. J. Vet. Cardiol. 2016, 18, 248-254. [CrossRef]

319. Adin, D.; Atkins, C.; Papich, M.; Defrancesco, T.C.; Griffiths, E.; Penteado, M.; Kurtz, K.; Klein, A. Furosemide continuous rate infusion diluted with $5 \%$ dextrose in water or hypertonic saline in normal adult dogs: A pilot study. J. Vet. Cardiol. 2017, 19, 44-56. [CrossRef]

320. Konta, M.; Nagakawa, M.; Sakatani, A.; Akabane, R.; Miyagawa, Y.; Takemura, N. Evaluation of the inhibitory effects of telmisartan on drug-induced reninangiotensin- aldosterone system activation in normal dogs. J. Vet. Cardiol. 2018, 20, 376-383. [CrossRef] [PubMed]

321. Goya, S.; Wada, T.; Shimada, Z.; Hirao, D.; Tanaka, R. Effects of high-dose alacepril on left atrial pressure and central aortic pressure in awake dogs with mitral valve regurgitation. Vet. J. 2019, 245, 7-11. [CrossRef]

322. Hori, Y.; Taira, H.; Nakajima, Y.; Ishikawa, Y.; Yumoto, Y.; Maekawa, Y.; Oshiro, A. Inotropic effects of a single intravenous recommended dose of pimobendan in healthy dogs. J. Vet. Med. Sci. 2019, 81, 22-25. [CrossRef]

323. Potter, B.M.; Ames, M.K.; Hess, A.; Poglitsch, M. Comparison between the effects of torsemide and furosemide on the reninangiotensin- aldosterone system of normal dogs. J. Vet. Cardiol. 2019, 26, 51-62. [CrossRef]

324. Treseder, J.R.; LeBlanc, N.L.; Scollan, K.F. Inotropic and chronotropic effects of sotalol in healthy dogs. J. Vet. Cardiol. 2019, 25, 14-24. [CrossRef] [PubMed]

325. Ovaert, P.; Elliott, J.; Bernay, F.; Guillot, E.; Bardon, T. Aldosterone receptor antagonists-How cardiovascular actions may explain their beneficial effects in heart failure. J. Vet. Pharmacol. Ther. 2010, 33, 109-117. [CrossRef]

326. Boswood, A. Current use of pimobendan in canine patients with heart disease. Vet. Clin. N. Am. Small Anim. Pract. 2010, 40, 571-580. [CrossRef]

327. Disatian, S. Myxomatous Degenerative Mitral Valve Disease: An Update. Thai Vet. Med. 2010, 40, $151-157$.

328. Kellihan, H.B.; Stepien, R.L. Pulmonary hypertension in dogs: Diagnosis and therapy. Vet. Clin. N. Am. Small Anim. Pract. 2010, 40, 623-641. [CrossRef]

329. Borgarelli, M.; Häggström, J. Canine degenerative myxomatous mitral valve disease: Natural history, clinical presentation and therapy. Vet. Clin. N. Am. Small Anim. Prac. 2010, 40, 651-663. [CrossRef]

330. Bowles, D.; Fry, D. Pimobendan and its use in treating canine congestive heart failure. Compendium 2011, 33, E1.

331. Oyama, M.A. Canine heart failure-early diagnosis, prompt treatment. NAVC Clin. Brief 2011, 9.

332. Jenkins, H.; Pace, C. Nursing approach: Clinical nutrition of the canine with cardiac disease. Vet. Nurse 2012, 3, 148-153. [CrossRef]

333. Kellihan, H.B.; Stepien, R.L. Pulmonary hypertension in canine degenerative mitral valve disease. J. Vet. Cardiol. 2012, 14, 149-164. [CrossRef] [PubMed]

334. Atkins, C.E.; Häggström, J. Pharmacologic management of myxomatous mitral valve disease in dogs. J. Vet. Cardiol. 2012, 14, 165-184. [CrossRef]

335. Boyle, K.L.; Leech, E. A review of the pharmacology and clinical uses of pimobendan. J. Vet. Emerg. Crit. Care 2012, 22, 398-408. [CrossRef] [PubMed]

336. Omamegbe, J.O.; Nwoha, R.I.O. Heart failure in small animals-Advances in clinical case management. Niger. Vet. J. $2013,34$.

337. Burchell, R.K.; Schoeman, J. Medical management of myxomatous mitral valve disease: An evidence-based veterinary medicine approach. J. S. Afr. Vet. Assoc. 2014, 85, 1-7. [CrossRef]

338. Andréjak, J. Management of chronic heart failure dog caused by mitral valve disease. Point Vétérinaire 2015, 46, 62-66.

339. Petrič, A.D. Myxomatous Mitral Valve Disease in Dogs-An Update and Perspectives. Maced. Vet. Rev. 2015, 38, 13-20. [CrossRef]

340. Ames, M.K.; Atkins, C.E. Beyond furosemide: The role of diuretics in congestive heart failure part 2: Spironolactone. Today's Vet. Pract. 2016, 6, 87-92.

341. Poser, H.; Guglielmini, G. Pulmonary hypertension in the dog. Acta Vet.-Beogr. 2016, 66, 1-25. [CrossRef]

342. Menciotti, G.; Borgarelli, M. Review of Diagnostic and Therapeutic Approach to Canine Myxomatous Mitral Valve Disease. Vet. Sci. 2017, 4, 47. [CrossRef]

343. Sewell, D. Myxomatous mitral valve disease in dogs part 2: Management. Companion Anim. 2017, 22, 60-70. [CrossRef]

344. Turgut, K.; Süleymanoğlu, H.; Ertan, M.; Ince, M. Geriatric Cardiology in Dogs—Part 1: Classification and Treatment of Heart Failure in Geriatrics. Kafkas Üniversitesi Vet. Fakültesi Derg. 2018, 24, 159-167. [CrossRef] 
345. Ames, M.K.; Atkins, C.E.; Pitt, B. The renin-angiotensin-aldosterone system and its suppression. J. Vet. Intern. Med. 2019, 33, 363-382. [CrossRef] [PubMed]

346. Hoque, M.; Saxena, A.C.; Gugjoo, M.B.; Bodh, D. Cardiac diseases in dogs. Indian J. Anim. Health 2019, 58, 1-20. [CrossRef]

347. Mochel, J. A Review of Relevant Therapeutic Targets for the Management of Congestive Heart Failure in Dogs: Present and Future Directions. Preprints 2019.

348. Packham, L. In dogs with congestive heart failure, is torasemide superior to furosemide as a first line diuretic treatment? Vet. Evid. 2020, 5, 4. [CrossRef]

349. Pedro, B.; Fontes-Sousa, A.P.; Gelzer, A.R. Diagnosis and management of canine atrial fibrillation. Vet. J. 2020, 265, 105549. [CrossRef]

350. Brown, A.J.; Davison, E.; Sleeper, M.M. Clinical Efficacy of Sildenafil in Treatment of Pulmonary Arterial Hypertension in Dogs. J. Vet. Intern. Med. 2010, 24, 850-854. [CrossRef]

351. Jaffey, J.A.; Leach, S.B.; Kong, L.R.; Wiggen, K.E.; Bender, S.B.; Reinero, C.R. Clinical efficacy of tadalafil compared to sildenafil in treatment of moderate to severe canine pulmonary hypertension: A pilot study. J. Vet. Cardiol. 2019, 24, 7-19. [CrossRef]

352. Ueda, Y.; Johnson, L.R.; Ontiveros, E.S.; Visser, L.C.; Gunther-Harrington, C.T.; Stern, J.A. Effect of a phosphodiesterase5A (PDE5A) gene polymorphism on response to sildenafil therapy in canine pulmonary hypertension. Sci. Rep. 2019, 9, 6899. [CrossRef]

353. Saetang, K.; Disatian, S. Short-term effects of sildenafil in the treatment of dogs with pulmonary hypertension secondary to degenerative mitral valve disease. Vet. World 2020, 13, 2260-2268. [CrossRef] [PubMed]

354. Arita, S.; Arita, N.; Hikasa, Y. Therapeutic effect of low-dose imatinib on pulmonary arterial hypertension in dogs. Can Vet. J. 2013, 54, 255-261. [PubMed]

355. Cunningham, S.M.; Rush, J.E.; Freeman, L.M. Short-Term Effects of Atorvastatin in Normal Dogs and Dogs with Congestive Heart Failure Due to Myxomatous Mitral Valve Disease. J. Vet. Intern. Med. 2013, 27, 985-989. [CrossRef]

356. Thassakorn, P.; Patchanee, P.; Pongkan, W.; Chattipakorn, N.; Boonyapakorn, C. Effect of atorvastatin on oxidative stress and inflammation markers in myxomatous mitral valve disease in dogs: A comparison of subclinical and clinical stages. J. Vet. Pharmacol. Ther. 2019, 42, 258-267. [CrossRef]

357. Tachampa, K.; Lertwanakarn, T.; Atchariyasakchai, P.; Pumpitakkul, V.; Kireewan, S.; Buranakarl, C. Effects of coenzyme Q10 supplementation on cardiac troponin i level, heart rate vari-ability, and echocardiographic profiles in canine with myxomatous degenerative mitral valve disease: A pilot study. Thai J. Vet. Med. 2018, 48, 443-452.

358. Christiansen, L.B.; Morsing, M.K.; Reimann, M.J.; Martinussen, T.; Birlie, Z.; Schou-Pedersen, A.M.V.; Lykkesfeldt, J.; Olsen, L.H. Pharmacokinetics of Repeated Oral Dosing with Coenzyme Q10 in Cavalier King Charles Spaniels with Myxomatous Mitral Valve Disease. Antioxidants 2020, 9, 827. [CrossRef]

359. Duarte, C.N.; Larsson, M.H.M.A. Adverse Effects of amlodipine on the treatment of heart failure in dogs with myxomatous mitral valve disease: Preliminary results. J. Vet. Intern. Med. 2019, 33, 1073-1074.

360. Yata, M.; Kooistra, H.S.; Beijerink, N. Cardiorenal and endocrine effects of synthetic canine BNP1-32 in dogs with compensated con-gestive heart failure caused by myxomatous mitral valve disease. J. Vet. Intern. Med. 2019, 33, 462-470. [CrossRef]

361. Ibarrola, J.; Garcia-Peña, A.; Matilla, L.; Bonnard, B.; Sádaba, R.; Arrieta, V.; Alvarez, V.; Fernández-Celis, A.; Gainza, A.; Navarro, A.; et al. A New Role for the Aldosterone/Mineralocorticoid Receptor Pathway in the Development of Mitral Valve Prolapse. Circ. Res. 2020, 127, e80-e93. [CrossRef]

362. Chetboul, V.; Pouchelon, J.L.; Menard, J.; Blanc, J.; Desquilibet, L.; Petit, A.; Rougier, S.; Lucats, L.; Woehrlé, F.; The TEST Study Investigators. Short-Term Efficacy and Safety of Torasemide and Furosemide in 366 Dogs with Degen-erative Mitral Valve Disease: The TEST Study. J. Vet. Intern. Med. 2017, 31, 1629-1642. [CrossRef]

363. Besche, B.; Blondel, T.; Guillot, E.; Garelli-Paar, C.; Oyama, M.A. Efficacy of oral torasemide in dogs with degenerative mitral valve disease and new onset con-gestive heart failure: The CARPODIEM study. J. Vet. Intern. Med. 2020, 34, 1746-1758. [CrossRef] [PubMed]

364. Bernay, F.; Bland, J.M.; Häggström, J.; Baduel, L.; Combes, B.; Lopez, A.; Kaltsatos, V. Efficacy of Spironolactone on Survival in Dogs with Naturally Occurring Mitral Regurgitation Caused by Myxomatous Mitral Valve Disease. J. Vet. Intern. Med. 2010, 24, 331-341. [CrossRef]

365. Schuller, S.; Van Israël, N.; Vanbelle, S.; Clercx, C.; McEntee, K. Lack of efficacy of low-dose spironolactone as adjunct treatment to conventional congestive heart failure treatment in dogs. J. Vet. Pharmacol. Ther. 2011, 34, 322-331. [CrossRef]

366. Oyama, M.A.; Peddle, G.D.; Reynolds, C.A.; Singletary, G.E. Use of the loop diuretic torsemide in three dogs with advanced heart failure. J. Vet. Cardiol. 2011, 13, 287-292. [CrossRef] [PubMed]

367. Peddle, G.D.; Singletary, G.E.; Reynolds, C.A.; Trafny, D.J.; Machen, M.C.; Oyama, M.A. Effect of torsemide and furosemide on clinical, laboratory, radiographic and quality of life variables in dogs with heart failure secondary to mitral valve disease. J. Vet. Cardiol. 2012, 14, 253-259. [CrossRef] [PubMed]

368. Lefebvre, H.P.; Ollivier, E.; Atkins, C.E.; Combes, B.; Concodet, D.; Katlsatos, V.; Baduel, L. Safety of Spironolactone in Dogs with Chronic Heart Failure because of Degenerative Valvular Disease: A Population-Based, Longitudinal Study. J. Vet. Intern. Med. 2013, 27, 1083-1091. [CrossRef] 
369. Loughran, K.A.; Larouche-Lebel, E.; Huh, T.; Testani, J.M.; Rao, V.S.; Oyama, M.A. Prediction and measurement of diuretic responsiveness after oral administration of furosemide to healthy dogs and dogs with congestive heart failure. J. Vet. Intern. Med. 2020, 34, 2253-2264. [CrossRef] [PubMed]

370. Häggström, J.; Boswood, A.; O'Grady, M.; Jöns, O.; Smith, S.; Swift, S.; Borgarelli, M.; Gavaghan, B.; Kresken, J.G.; Patteson, M.; et al. Longitudinal Analysis of Quality of Life, Clinical, Radiographic, Echocardiographic, and Laboratory Variables in Dogs with Myxomatous Mitral Valve Disease Receiving Pimobendan or Benazepril: The QUEST Study. J. Vet. Intern. Med. 2013, 27, 1441-1451. [CrossRef]

371. Boswood, A.; Häggström, J.; Gordon, S.G.; Wess, G.; Stepien, R.L.; Oyama, M.A.; Keene, B.E.; Bonagura, J.; MacDonald, K.A.; Patteson, M.; et al. Effect of Pimobendan in Dogs with Preclinical Myxomatous Mitral Valve Disease and Cardiomegaly: The EPIC Study-A Randomized Clinical Trial. J. Vet. Intern. Med. 2016, 6, 1765-1779. [CrossRef]

372. Häggström, J.; Lord, P.F.; Höglund, K.; Ljungvall, I.; Jöns, O.; Kvart, C.; Hansson, K. Short-Term Hemodynamic and Neuroendocrine Effects of Pimobendan and Benazapril in Dogs with Myxomatous Mitral Valve Disease and Congestive Heart Failure. J. Vet. Intern. Med. 2013, 27, 1452-1462. [CrossRef]

373. Kim, W.; Park, H. Clinical efficacy and safety of imidapril in dogs with congestive heart failure. J. Vet. Intern. Med. 2015, $29,1151$.

374. Marcondes-Santos, M.; Mansur, A.P.; Fragata, F.S.; Strunz, C.M.C. Short-term follow-up of exercise training program and beta-blocker treatment on quality of life in dogs with naturally acquired chronic mitral valve disease. Braz. J. Med. Biol. Res. 2015, 48, 886-894. [CrossRef] [PubMed]

375. Mocanu, D.; Baisan, A.; Stanciu, G.; Armasu, M.; Musteata, M.; Solcan, G. Assessment of the therapeutically efficiency of benazepril-furosemide bimedication from a clinical and echocardiographic point of view in dogs with mitral valve endocardiosis. Lucr. Ştiinţifice Med. Vet. 2015, 48, 95-106.

376. Lake-Bakaar, G.A.; Singh, M.K.; Kass, P.H.; Griffiths, L.G. Effect of pimobendan on the incidence of arrhythmias in small breed dogs with myxomatous mitral valve degeneration. J. Vet. Cardiol. 2015, 17, 120-128. [CrossRef] [PubMed]

377. Jung, S.W.; Sun, W.; Griffiths, L.G.; Kittleson, M.D. Atrial Fibrillation as a Prognostic Indicator in Medium to Large- Sized Dogs with Myxomatous Mitral Valvular Degeneration and Congestive Heart Failure. J. Vet. Intern. Med. 2016, 30, 51-57. [CrossRef]

378. Disatian, S.; Boonlue, N.; Pupa, P.; Boonsathitanan, W.; Rakthaidee, S.; Mangklabruks, T.; Sakarin, S. Electrocardiographic Changes in Dogs with Degenerative Mitral Valve Disease Treated with Pimobendan: A Retrospective Study of 29 Cases. Thai J. Vet. Med. 2016, 46, 243-249.

379. Mizuno, M.; Yamano, S.; Chimura, S.; Hirakawa, A.; Takusagawa, Y.; Sawada, T.; Maetani, S.; Takahashi, A.; Mizuno, T.; Harada, K.; et al. Efficacy of pimobendan on survival and reoccurrence of pulmonary edema in canine congestive heart failure. $J$. Vet. Med. Sci. 2017, 79, 29-34. [CrossRef]

380. King, J.N.; Hirakawa, A.; Sonobe, J.; Otaki, H.; Sakakibara, N.; Seewald, W.; Forster, S. Evaluation of a fixed-dose combination of benazepril and pimobendan in dogs with congestive heart failure: A randomized non-inferiority clinical trial. J. Vet. Sci. 2018, 19, 117-128. [CrossRef]

381. Uemura, A.; Hamabe, L.; Shimada, K.; Shimizu, M.; Tanaka, R. Evaluation of symptomatic improvements observed by switching to alacepril from other ACE-Inhibitors in dogs with mitral valve regurgitation. Thai J. Vet. Med. 2018, 48, 29-36.

382. Varshney, J.P.; Huma, Z.I.; Sharma, N. Evaluation of cardiac troponin-i and vitamin D3 in dogs with left heart failure and its management using pimobendan. Vet. Pract. 2019, 20, 74-77.

383. Lee, J.; Ahn, H. The misuse (overdose) of pimobendan may potentially induce myocardial fatigue in dogs with myxomatous mitral valve disease. J. Vet. Intern. Med. 2019, 33, 1038-1039.

384. Wess, G.; Kresken, J.; Wendt, R.; Gaugele, J.; Killich, M.; Keller, L.; Simak, J.; Holler, P.; Bauer, A.; Küchenhof, H.; et al. Efficacy of adding ramipril (VAsotop) to the combination of furosemide (Lasix) and pimobendan (VEtmedin) in dogs with mitral valve degeneration: The VALVE trial. J. Vet. Intern. Med. 2020, 34, 2232-2241. [CrossRef]

385. Beaumier, A.; Rush, J.E.; Yang, V.K.; Freeman, L.M. Clinical findings and survival time in dogs with advanced heart failure. J. Vet. Intern. Med. 2018, 32, 944-950. [CrossRef] [PubMed]

386. Mohammadyar, L.; Molazem, M. Follow up the Treatment Process of Mitral Valve Diseases by Radiography and Echocardiography in Dogs. Iran J. Vet. Med. 2019, 13, 123-130.

387. Ames, M.K.; Atkins, C.E.; Eriksson, A.; Hess, A.M. Aldosterone breakthrough in dogs with naturally occurring myxomatous mitral valve disease. J. Vet. Cardiol. 2017, 19, 218-227. [CrossRef]

388. Freeman, L.M.; Rush, J.E.; Cunningham, S.M.; Yang, V.K.; Bulmer, B.J. Pilot study of a myostatin antagonist in dogs with cardiac cachexia. J. Vet. Cardiol. 2015, 17, 210-215. [CrossRef] [PubMed]

389. Wolf, J.; Gerlach, N.; Weber, K.; Klima, A.; Wess, G. Lowered N-terminal pro-B-type natriuretic peptide levels in response to treatment predict survival in dogs with symptomatic mitral valve disease. J. Vet. Cardiol. 2012, 14, 399-408. [CrossRef]

390. Hezzell, M.J.; Block, C.L.; Laughlin, D.S.; Oyama, M.A. Effect of prespecified therapy escalation on plasma NT-proBNP concentrations in dogs with stable congestive heart failure due to myxomatous mitral valve disease. J. Vet. Intern. Med. 2018, 32, 1509-1516. [CrossRef]

391. Schober, K.E.; Hart, T.M.; Stern, J.A.; Li, X.; Samii, V.F.; Zekas, L.J.; Scansen, B.A.; Bonagura, J.D. Effects of treatment on respiratory rate, serum natriuretic peptide concentration, and doppler echocardiographic indices of left ventricular filling pressure in dogs with congestive heart failure secondary to degenerative mitral valve disease and dilated cardiomyopathy. J. Am. Vet. Med. Assoc. 2011, 239, 468-479. 
392. Lee, J.; Kim, W. Potential renoprotective effect of angiotensin-receptor antagonists in dogs with myxomatous mitral valve disease. J. Vet. Intern. Med. 2020, 34, 393.

393. Davies, T.; Everitt, S.; Cobb, M. Variation in the management of congestive cardiac failure in dogs. Vet. Rec. 2015, $176,435$. [CrossRef] [PubMed]

394. Coffman, M.; Guillot, E.; Blondel, T.; Garelli-Paar, C.; Feng, S.; Heartsill, S.; Atkins, C.E. Clinical efficacy of a benazepril and spironolactone combination in dogs with congestive heart failure due to myxomatous mitral valve disease: The BEnazepril Spironolactone STudy (BESST). J. Vet. Intern. Med. 2021, 35, 1673-1687. [CrossRef] [PubMed] 